\title{
System Dynamics Modeling of Indium Material Flows under Wide Deployment of Clean Energy Technologies
}

Chul Hun Choia, Jinjian Caoa, Fu Zhao ${ }^{b^{*}}$

aSchool of Industrial Engineering, Purdue University, 315 N. Grant Street, West Lafayette, IN, U.S.A.

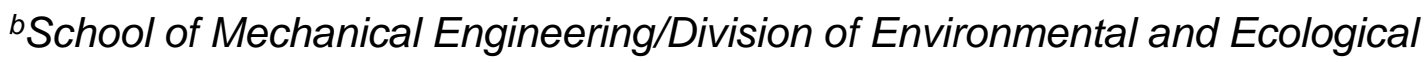
Engineering, Purdue University, 585 Purdue Mall, West Lafayette, IN, U.S.A.

"Corresponding author: Fu Zhao, School of Mechanical Engineering, Purdue University, 585 Purdue Mall, West Lafayette, Indiana, USA. Email: fzhao@purdue.edu

\section{Abstract}

Clean energy technologies represent a promising solution to the global warming challenge. Many clean energy technologies, however, depend on some rare materials and concerns have been raised recently. Indium is one of these materials as it is critical for two emerging energy applications, that is, Copper indium gallium selenide (CIGS) photovoltaics (PV) and light-emitting diode (LED) lighting. This study analyzes the supply and demand of indium under different energy and technology development scenarios using a dynamic material flow analysis approach. A system dynamics model is developed to capture the time-changing stocks and flows related to supply and demand of indium over a 50-year time period, while considering carrier metal (i.e. zinc) production, price elasticity of demand, and indium usage in other 
applications (mainly liquid crystal display). Simulation results indicate that a shortage on indium is likely to occur in a short time period even under favorite case of indium supply. The rapid expansion of CIGS technology dominates indium demand in about 14 years, which outruns the growth of zinc mine production (thus indium supply). Sensitivity analysis suggests that model parameters related to solar PV market penetration, CIGS technology advancement, and price elasticity of indium demand have large effects on the total indium demand over simulation period. Eight scenarios combining projections on solar PV market growth, technology advancement, and zinc mine production are explored. It is observed that only under conservative estimates of solar PV market growth there is relatively enough indium supply to support the deployment. Even in these scenarios a shortage may occur toward the end of simulation.

\section{Keywords}

Material criticality, Supply risk, Dynamic material flow analysis, Thin-film photovoltaic (CIGS), LED lighting, Indium

\section{Introduction}

Energy is one of the most important utilities for modern society, with demand continuously increasing as the world becomes more industrialized. A majority (87\%) of global energy consumption relies on fossil fuels (BP, 2013). The dependency on fossil fuels has raised serious concerns on global warming and climate changes. Clean energy technologies have emerged as a promising solution, which aims at utilizing renewable energy sources and improving energy efficiency. The Critical Materials Strategy Report by U.S. Department of Energy (DOE), however, pointed 
out that many clean energy technologies rely on rare materials (US DOE, 2011). 16 materials (Li, Mn, Co, Ni, Ga, Y, In, Te, La, Ce, Pr, Nd, Sm, Eu, Tb, Dy) were analyzed in the report for their "criticality", which is determined in two dimensions, that is, importance to clean energy and supply risk.

One of the critical materials studied in the DOE report is indium. Indium is a post-transition metallic element that has an atomic number of 49 . It is primarily used for producing indium tin oxide (ITO), a key material for manufacturing liquid crystal display (LCD) panels (USGS, 2009c). Because ITO had been responsible for a majority of indium consumption and the demand from clean energy technologies has been minimal in the past, indium was reported as a near critical material in the DOE report (all the critical materials identified are rare earth elements) (US DOE, 2011). Given indium, however, is needed in several fast growing clean energy applications, in particular thin-film photovoltaic (PV) and light emitting diode (LED) lighting (USGS, $2012 b)$, the material sustainability and criticality of indium should be closely examined.

In addition to the potential demands from clean energy technologies, the fact that indium is mainly produced as a byproduct of zinc mining and refining makes the indium supply-demand scenarios more interesting. One tool that could be used to analyze these complex scenarios is material flow analysis (MFA), which is an analytical methodology that quantifies the flow of a material of interest in a defined system. MFA has found applications in a wide range of applications, ranging from resource conservation, environmental management to regional material management (Bruner and Rechberger, 2004; Huang et al., 2012). Many studies in materials management, especially for metals, used MFA as a tool in various temporal and spatial boundaries. (Buchner et al., 2014; Bicanová et al., 2015; Leal-Ayala et al., 
2015; Wang et al. 2015). MFA of indium has also been conducted in several researches. For example, USGS performed an analysis on indium material flows within the United States for year 2008 (Goonan, 2012). There are also MFA studies on indium with focus on flat panel display (Nakajima et al., 2007; Yoshimura et al., 2013). Traditional MFA analyses are largely "static", that is, they only show a snapshot of material flows within a determined boundary for a specified time period in the past. To study the future supply and demand of indium and how the material flows are affected by the wide deployment of clean energy technologies, a "dynamic" MFA is needed.

According to a review done by Müller et al. (2014), the methodology of dynamic MFAs was first developed by Baccini and Bader in 1996, with the first studies on metals published in 1999 for copper in the United States (Zeltner et al.,1999) and for aluminum in Germany (Melo, 1999). To date, there are more than 60 dynamic MFA studies on metals published (Müller et al., 2014). No standard methodology or protocol for dynamic MFA of metals, however, has been established: modeling approach, spatial/temporal scale, and system boundary vary from study to study. In general, stock and flow models are used for dynamic MFA and system dynamics (SD) simulation seems to be a powerful tool for this purpose.

SD can model complex dynamic systems for better understanding of nonlinear behavior over time in a defined system (Matsuno et al., 2012; Morf et al., 2008; Hatayama et al., 2007; Kleijn et al., 2000). A handful of efforts have been made to adapt SD in dynamic MFA. Glöser et al. (2013) studied global copper flow using SD methodology. Pruyt (2010) developed a SD model for generic scarce minerals and performed sensitivity analysis to explore system behavior over time. Recently, Houari et al. (2014) developed SD model to predict tellurium availability for CdTe PV. It 
should be pointed out that this study did not consider the effects of market price on the supply and demand.

Dynamic MFA studies on indium have been rare. Zuser and Rechberger (2011) and Zimmerman (2013) analyzed the material demand and resource availability for metals (including indium) critical for PV industries, while considering PV market growth, material intensity, and material efficiency in production. Although being discussed, the issues of indium as a by-product from zinc mining and the competitive usage from electronics industry and other emerging technologies are not modeled. The most advanced (and most recent) study is the one by Stamp et el., in which indium demands related to the implementation of different energy system transition scenarios were simulated using SD (Stamp et al., 2014). The study considered the indium demands from flat panel display and other applications, as well as the possible responses from the supply system to the increasing demands, including improving extraction efficiency, increasing production of carrier metal zinc, mining indium with other carrier metals, and accessing historic residues. As noted by the authors, however, the SD model developed is a much simplified one. That is, the model does not internally generate dynamics via feedback loops. Instead, the dynamics is externally driven by the PV market penetration scenarios and the factors affecting the supply and demand are simulated separately. In this research, a more integrated SD model will be developed to include market/price mediated supply and demand responses of both zinc and indium, and other emerging clean energy technology (i.e. LED) that contributes to increased indium demand.

\section{Model description}

\subsection{Purpose and implementation}


Main purpose of this model is to explore the dynamic balance between global supply and demand of indium under different clean energy technology adoption and economic growth scenarios over next 50 years. The time period encompasses market saturation of both LED and solar PV as well as the phase-out of LCD. Analysis of results from these scenarios could provide insights on whether indium supply will be a limiting factor for wide deployment of clean energy technologies and the possible root causes. For this purpose, standard SD modeling approach is followed. System boundary is first defined, followed by constructing causal loop diagram which visualizes how variables (stocks and flows) in the model are influencing each other. The stock and flow diagrams are then constructed for simulation, using commercial software Powersim Studio 10. Model validation is performed before implementing different scenarios.

\subsection{System boundary of the model}

For SD simulation, including all factors that play a role in the system being studied could be very challenging (and costly), although the accuracy or reliability of the results could be increased by including more entities in the model. Therefore, a common practice is to define a reasonable system boundary and analysis is conducted within that boundary. Figure 1 shows the system boundary considered in this research. Because indium is a by-product of zinc mining and refining, demand and supply of zinc have to be included. Zinc supply relies on both primary production (i.e. mining from the earth) and secondary production (i.e. recycling from end of life products). Zinc demand is mainly influenced by economic growth since the major demand for zinc is steel galvanization in construction and automobile industry (USGS, 2012c). As with other commodity, market price also affects its demand. 
On the demand side, ITO manufacturing accounts for $80 \%$ of indium consumption, followed by alloys and solders (USGS, 2009c). Here the demands of indium for alloys and solders are grouped with all other minor demands and are assumed to be constant over time. Thin-film PV and LED (in flat panel display and lighting) each account for less than $2 \%$ of global indium consumptions (USGS, 2008), but they represent potential major demand sources of indium in the future.

It should be noted that there are three major thin film PV technologies under development, that is, Cadmium Telluride (CdTe), amorphous silicon (a-Si), and Copper Indium Gallium Selenide (CIGS), with CdTe dominating the thin film market now (Fraunhofer Institute, 2012). Compared to the other two types of thin-film technologies, CIGS has higher conversion efficiency along with lower manufacturing cost and also does not require toxic material such as cadmium (Dimmler, 2012). A-Si technology and CdTe system are excluded from system boundary of this research because of their lack of mandatory indium requirement during module manufacturing. 


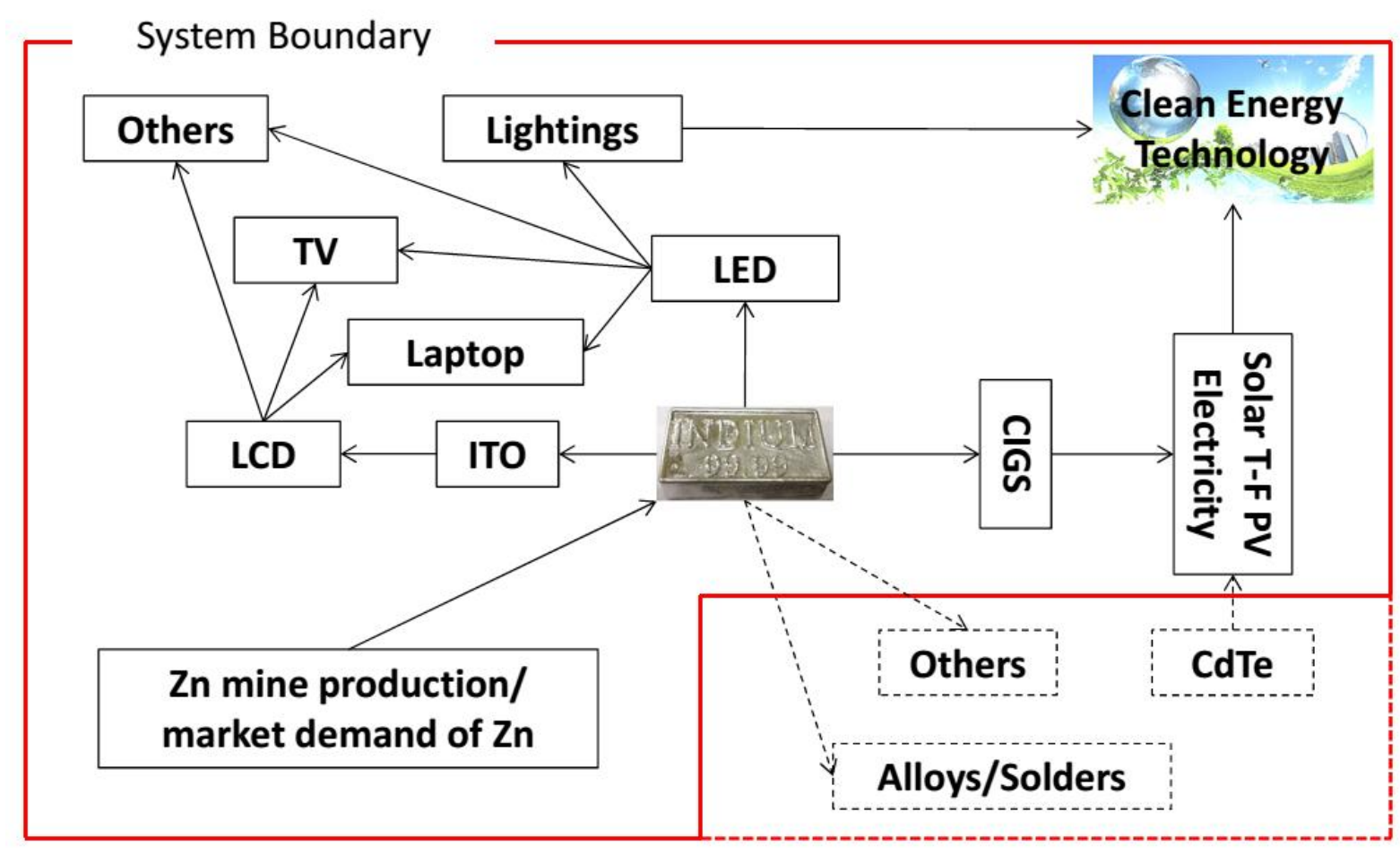

Figure 1 System boundary of indium material flow analysis.

\subsection{Causal loop diagram (CLD)}

The CLD for indium material flow along with zinc supply and demand in this research is shown in Figure 2. Zinc demand is positively influenced by economic growth. High demand reduces zinc slab stock in the world, resulting in price increases of the mineral commodity, which in turn decrease the demand. This relationship is called negative (balancing) feedback in system dynamics, which represents a closed causal loop that has odd number of negative signed links. Zinc slab stock in the global market is also positively influenced by mine production as well as recycling from end of life products. The mine production is positively influenced by both zinc price and economic growth. In addition, mining (i.e. primary production) depletes remaining resources. However, depletion time of zinc reserve stay the same as 20 years (IZA, 2011b) during the past 50 years. This implies that 
new reserve is kept added through mine exploration and development. Therefore, it is reasonable to assume the zinc resource is far from depletion during the simulation period and zinc reserve has no effect on zinc price.

Different from zinc, current indium supply is almost exclusively from primary production and pre-consumer recycling. Indium production could lead to accumulation of indium stock while decreasing remaining indium sources (i.e. indium reserve). Indium reserve and indium stock are in reverse relationships with indium demands, which includes ITO, LED, and CIGS thin-film PV in this model. All these three indium demands are positively related with demand of the final products. Similar to zinc, there is also a negative (balancing) feedback loop consisting of indium demand, indium price, and supply/demand ratio. The supply and demand ratio also gives negative feedback to the supply of indium.

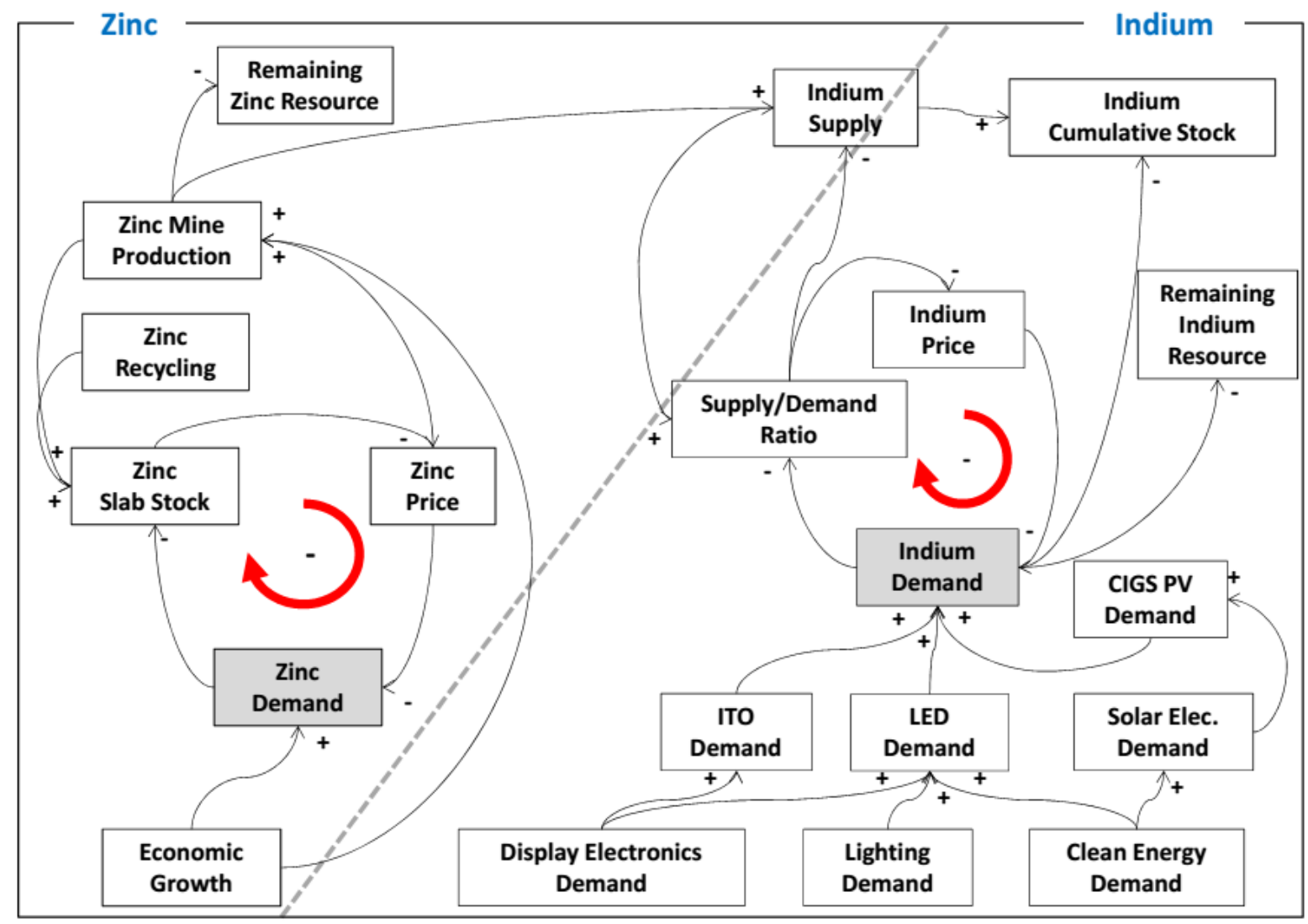

Figure 2 Causal loop diagram of the SD model. The diagonal dotted line divides zinc 
and indium loop. Links with arrows show the direction of impacts. Positive signs indicate changes of variables connected by the links move in same directions and negative signs represent changes in opposite directions.

\subsection{Stock flow diagram}

Generally, system dynamics model consists of stock, flow, and other auxiliary variables or constants that influence stocks or flows. All these components except flows are connected with single lined arrows (called "connectors"), while flows are shown as double lined arrows. Directions of arrows depend on influences and the relationships between the two nodes connected with each other. With these building blocks in SD model, a stock flow diagram (SFD) is constructed in Figure 3 based on the generic commodity SD model proposed by Sterman (2000) and Pruyt (2010) to show dynamic behavior of variables of interests. SD model in this research can be described in two separate yet interconnected parts which include zinc supply/demand and indium supply/demand.

\subsubsection{Zinc supply and demand}

The annual supply of zinc to the market is determined as the sum of 'refined zinc production' and zinc 'recycling'. The amount of zinc that is available for mining is represented as 'remaining resource'. In this model, zinc recycling is assumed to account for $15 \%$ of total supply and the percentage stays unchanged (IZA, 2011a).

In a general commodity market, 'annual extraction' of a commodity is limited by the extraction capacity, and actual amount of production is affected by many factors, including market conditions. For simplicity the level of 'zinc mine production' in this study is modeled based on historical data. Zinc mine production increased 
gradually with a cumulative average growth rate (CAGR) of $2.6 \%$ since 1990 and this is very similar to the world economic growth rate for last 20 years (around 3\%) (Kaiser, 2015; Tani, 2015). Therefore, 'zinc production increase rate' is modeled to be linked with 'global economic growth rate' (3\%, base case) in this model. To make it more realistic, 'zinc mine production' is set to be increased with the rate of 'global economic growth rate' only when the 'zinc market price' is greater than 'zinc production cost' and no growth is projected otherwise.

On the other hand, in the shorter term, annual zinc mine production has been stable in the past five years (USGS, 2012a, 2015) and world economy is also suffered from staggered growth after economic crisis in 2009. The report from World Bank supports this and the global economic growth rate is less than $2.5 \%$ in 2010 s (World Bank, 2015). To capture this recent staggered economic growth and conservative zinc mine production projection in the future, 'zinc production increase rate' (global economic growth rate) is set to be $2 \%$ in an alternative case.

The level of global 'zinc slab stock' is increased by 'refined zinc production' and 'recycling', and decreased by 'production of goods', which is a representative of zinc demand.

On the demand side, annual 'demand increase' is set as a flow into 'zinc annual demand' and is linked to 'global economic growth rate' that is assumed to be $3 \%$ (base case) in this research. Another variable that impacts 'zinc annual demand' level is 'zinc demand losses due to price elasticity'. In microeconomics, price elasticity of demand characterizes the demand changes in response to price changes and the higher the value of elasticity the more sensitive to the change of price the product or service is (Nicholson and Snyder, 2011). Zinc price elasticity is assumed to be 0.07 in this model (Stuermer, 2013). 
One notable point in this model is that the price adapted in finding demand loss is 'zinc market price', not 'zinc price'. Zinc price is calculated as the product of 'traders' expected zinc price' and 'effect of stock on price'. 'Zinc market price' is the larger between the 'zinc price' and 'zinc production cost' because market price of a commodity, in general, will not drop below the production cost. In order to reflect market condition, zinc production cost is modeled to increase with an 'average inflation rate' of 3\% (World Bank, 2015). The 'effect of stock on price' in this price setting model reflects sensitivity of price change to the mineral commodity stock in the market. Plotting yearly change rates of zinc price and stock from 2005 to 2008 suggests an inverse exponential relationship between the two and this relationship is applied to the 'effect of stock on price' (NRCan, 2009). Moreover, 'traders' expected zinc price' is a stock variable with the difference between 'zinc market price' and 'traders' expected zinc price' of previous year as an inflow.

In addition to this price setting process in this model, commodity price is also influenced by several other factors, for example, new technology, substitute products, and changes in the macro economy (Sterman, 2000). For simplicity, however, only traders' price expectation and inventory of zinc stock are taken into account in this research. Detail explanations of zinc supply and demand along with price setting process are described in Sections A.1.1 and A.1.2 of the supplementary material.

\subsubsection{Indium supply and demand}

Indium supply is determined by 'zinc mine production' and 'operation of indium circuit (nominal indium concentration)' and the amount of 'yearly indium supply' is the product of the two variables. Here the 'operation of indium circuit' is designed to have inverse linear relationship with 'supply and demand ratio'. More detail description of 
this relationship is presented in Section A.1.3 of the supplementary material.

The demand, which is the outflow from 'indium cumulative balance', consists of four components, that is, ITO, LED, thin film PV, and others. Since the goal of this research is to see the impact of three demands (ITO, LED, thin film PV), all other demands are grouped as one which is 'demand for others', with annual consumption assumed to stay the same over the simulation period.

The S shaped curve, that is, logistic function (Equation 1) can be used to simulate different stages of market growth of a new product or new technology (Bayus, 1998):

$$
\text { Market share }=L /\left\{1+a \times \exp ^{(-b t)}\right\}
$$

where $L$ is maximum value of the curve, $a$ is time to reach the maximum value and $b$ represents curve's steepness, and $t$ is the time.

Here growths of three indium demands are assumed to follow the $S$ shaped curve but the three technologies are at different stages. According to an industrial report (Semenza, 2010), LCD market has entered saturation phase. With this fact and global LCD market share trend, the $\mathrm{S}$ shaped curve is constructed, assuming that market share will increase five more percent than the current level. The $S$ shaped curve also describes that indium demand from the ITO manufacturing will decline after 15 years. Here the decline is modeled with a flipped $\mathrm{S}$ curve symmetric to its growth phase, assuming that either a new display technology or substitute for ITO in LCD display will emerge.

In considering ITO manufacturing for LCD market, there is another factor that needs to be considered. A key process in ITO manufacturing, sputtering, has relatively low material efficiency: only $30 \%$ of indium is sputtered on the panel and the rest $(70 \%$, recycle ratio) is sent to recycle with a 'recycle efficiency' of about $90 \%$ 
(Edison Investment, 2011; USGS, 2009a; Goonan, 2012).

LED market is at the exponential growth stage as per the 2012 report from McKinsey and Company and its growth rate is expected to persist at least up to 2020 with compound annual growth rate (CAGR) of $24 \%$. For this LED market share expansion, the $S$ shaped curve is constructed based on the data suggested by Yole development (Yole development, 2012).

Finally, solar PV market/CIGS market is assumed to be at the stage of infancy and the S shaped curves for both markets are constructed based on the data obtained from International Energy Agency (IEA) annual report (IEA, 2014) and industrial report by Cenergy Maxpower (Cenergy Maxpower, 2014), respectively. According to IEA report, solar PV market can be simulated in two different scenarios, one of which is called '2DS' and the other is 'hi-Ren' scenario (See Table A.1 in the Section A.1.3 of the supplementary material). The 2DS scenario is a strategic scenario that reduces global temperature rise to $2^{\circ} \mathrm{C}$ using renewable energy by 2050. The hi-Ren scenario, as a variant of 2DS scenario, is the most aggressive one that projects solar PV electricity as the largest among all renewable energy sources. This hi-Ren scenario expects solar PV system to generate $6,300 \mathrm{TWh}$ of total electricity and it accounts for $16 \%$ of total electricity generation in 2050 , comparing 4,000 TWh and 10\% in 2DS scenario. In this research, 2DS scenario is used for solar PV market penetration because hi-Ren scenario would lead to even worse indium shortage. In contrast to the availability of projections on total solar PV market up to 2050, CIGS market information is limited to the past thus assumption was made that the share of CIGS power generation will be $25 \%$ of total solar PV electricity in 2050 (Stamp et al., 2014; Zuser and Rechberger, 2011). Additionally, it is reported that solar PV system has life span of 28 years (Kumar and Sarkar, 2013). 
Replacement of old PV system requires additional solar PV module manufacturing and this is reflected in this model.

Factors that affect indium demand to support the CIGS penetration discussed above include 'irradiation per year', 'performance ratio', 'CIGS module efficiency', and material intensity (i.e. 'indium content per square meter of CIGS film' which is calculated from film thickness). This Indium demand can be calculated using Equation (2) below.

Demand by CIGS $=\{(C S E S) \times(I C P C F)\} /\{(I P R) \times(P R) \times(C M E)\}$

where CSES, ICPCM, IPR, PR, CME, represent CIGS Solar Electricity Supply, Indium Content Per $\mathrm{m}^{2}$ CIGS Film, Irradiation Per Year, Performance Ratio, CIGS Module Efficiency, respectively.

Range of 'irradiation per year' varies depending on the location of installation but is set to be constant in this model assuming all solar PV system will be installed under a favorable irradiation condition. The other three parameters are modeled with different scenarios to see how these factors affect indium demand by CIGS technology.

The market price of indium also has an impact on indium demand and the relationship is implemented in the model similar to zinc. That is, 'indium price' is calculated as the product of 'traders' expected indium price' and 'effect of shortage on price'. 'Actual indium demand', that represents expected indium demand after price consideration, is set as a stock variable for which inflow is annual change of 'primary production demand' and outflow is 'indium demand loss due to price elasticity'. That 'actual indium demand' is used to calculate 'supply demand ratio' and eventually contributes to indium price setting process loop. Inverse exponential function is assigned to the 'effect of shortage on price' to represent the relationship 
between the price change and the change of 'supply demand ratio' (Polinares, 2012 and Burgess 2007).

Finally, 'indium market price' is set to be the larger between the 'indium price' and 'indium production cost'. Indium production cost is also assumed to increase with an average inflation rate of 3\% (World Bank, 2015). Detail explanations of indium supply and demand along with price setting process are described in Sections A.1.3 and A.1.4 of the supplementary material.

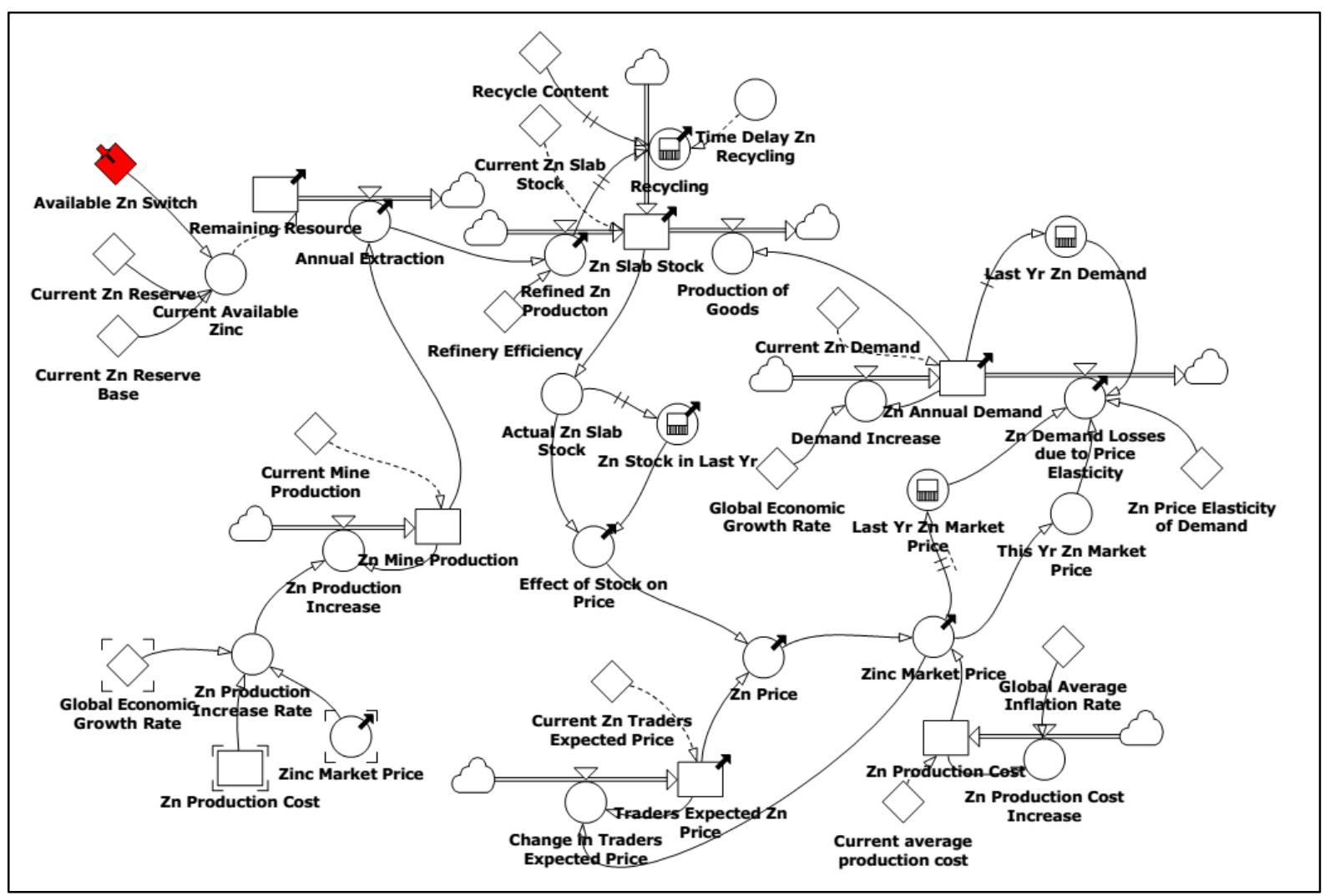




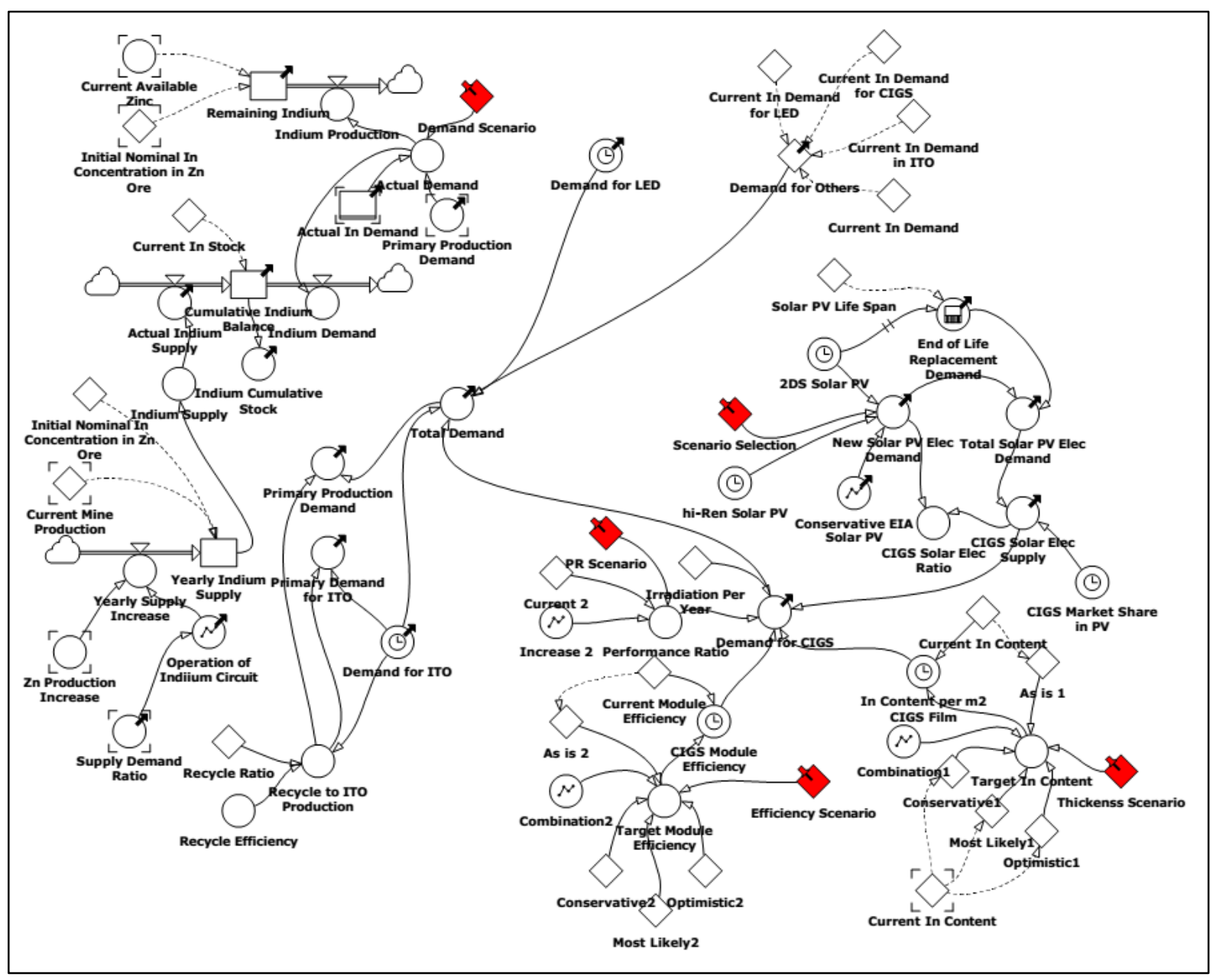




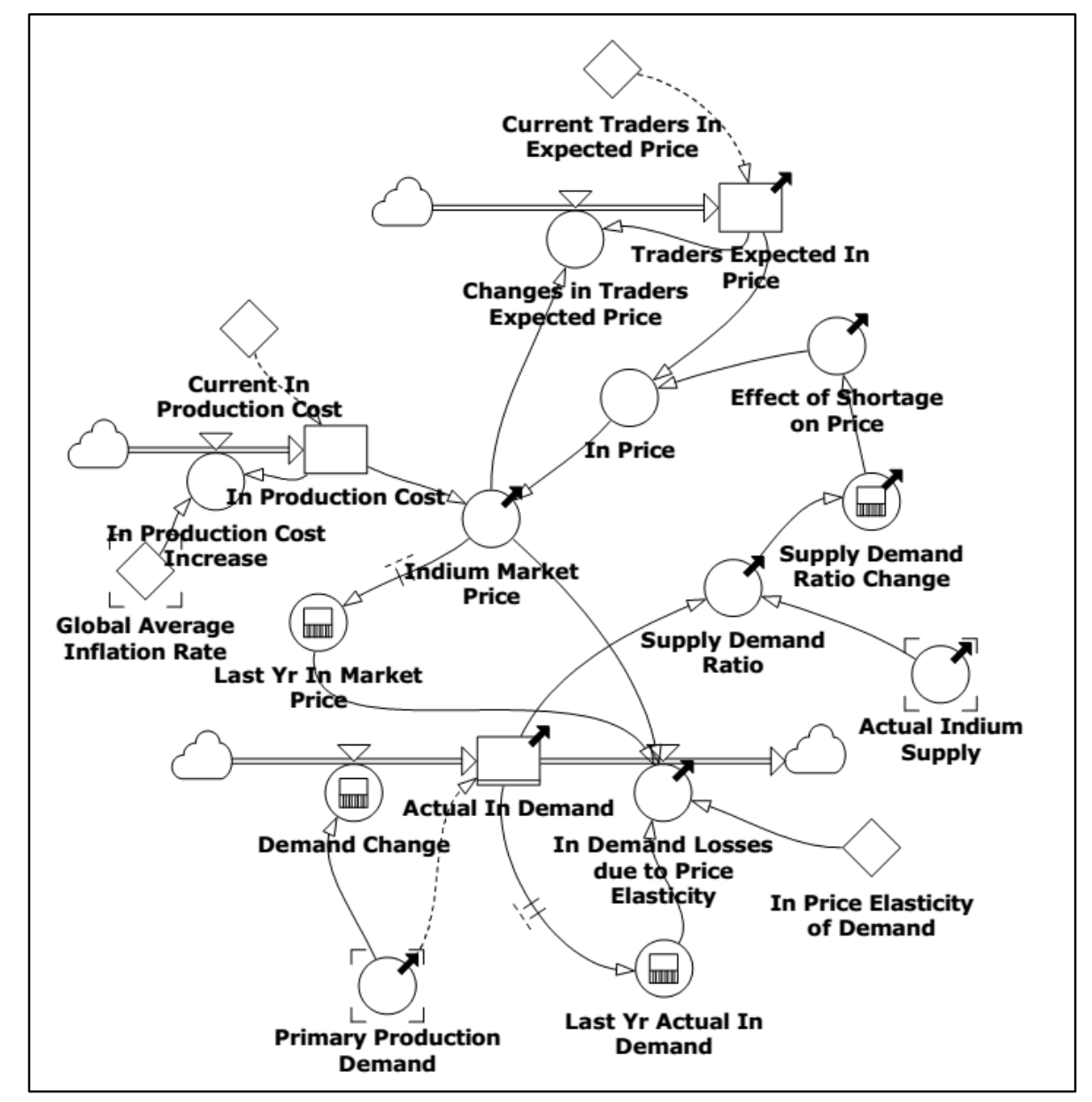

Figure 3 System dynamics model of zinc supply and demand (top), indium supply and demand (middle), and indium price setting model (bottom). Stocks: rectangles with variable names; Flows: valves in double lined arrows, Auxiliaries: circles, Constants: diamonds.

3. Model validation and scenario design

3.1. Model validation

SD models can be categorized as causal-descriptive (white-box) models since it seek to explain the dynamics of complex systems. Explanation of the behavior of the system and providing alternatives to achieve desired system behavior are the major goals of SD study (Saysel and Barlas, 2001). SD model's validity highly relies 
on 'internal structure' of the model rather than 'outputs' on which correlational (blackbox) models emphasize the most (Barlas, 1996). In addition to 'internal structure', 'behavior' of the model is also important in SD models. 'Structure validation' needs to be conducted first in order to give a meaningful 'behavior validation' (i.e. 'right behavior for the right reasons'). Moreover, point-by-point comparison between the model behavior and real system behavior is not as meaningful when compared to black-box models (Barlas, 1996; Saysel and Barlas, 2001).

To validate both structure and behavior of the SD model developed in this study, the formal validation procedures and tests proposed by Barlas (1996) are followed. To validate the structure, Barlas (1996) introduced two tests: direct structure test and structure-oriented behavior (indirect structure) test. SD model developed in this research is based on previous studies done by Sterman (2000) and Pruyt (2010) on generic mineral commodity. Furthermore, trends for all relationships between variables turned out to be consistent. Although these direct structure tests can validate the model structure in this study, they are neither objective nor quantitative (Saysel and Barlas, 2001). To compensate this disadvantage, indirect structure tests, i.e. extreme condition test and behavior sensitivity test are also performed.

\subsubsection{Extreme condition test}

There are two extreme conditions in the supply and demand ratio. One is infinite ratio and the other is zero ratio. The former one can be caused by either extremely high supply or very low demand and the latter due to the opposite cases. 'Global economic growth rate' and 'Indium price elasticity of demand' are chosen to control indium supply and demand, respectively. When high economic growth rate is 
applied indium supply spikes very high. The indium demand approaches zero with very high price elasticity of demand. Both lead to infinite supply-demand ratio. The antipodal trends are observed in the opposite cases. Here, only the cases that the ratio converges to zero are shown in the Figure 4 (left) because infinite supply and demand ratio cannot be visualized. Low economic growth rate of $0.1 \%$ and price elasticity of demand zero are used to represent very low supply and high demand cases, respectively.

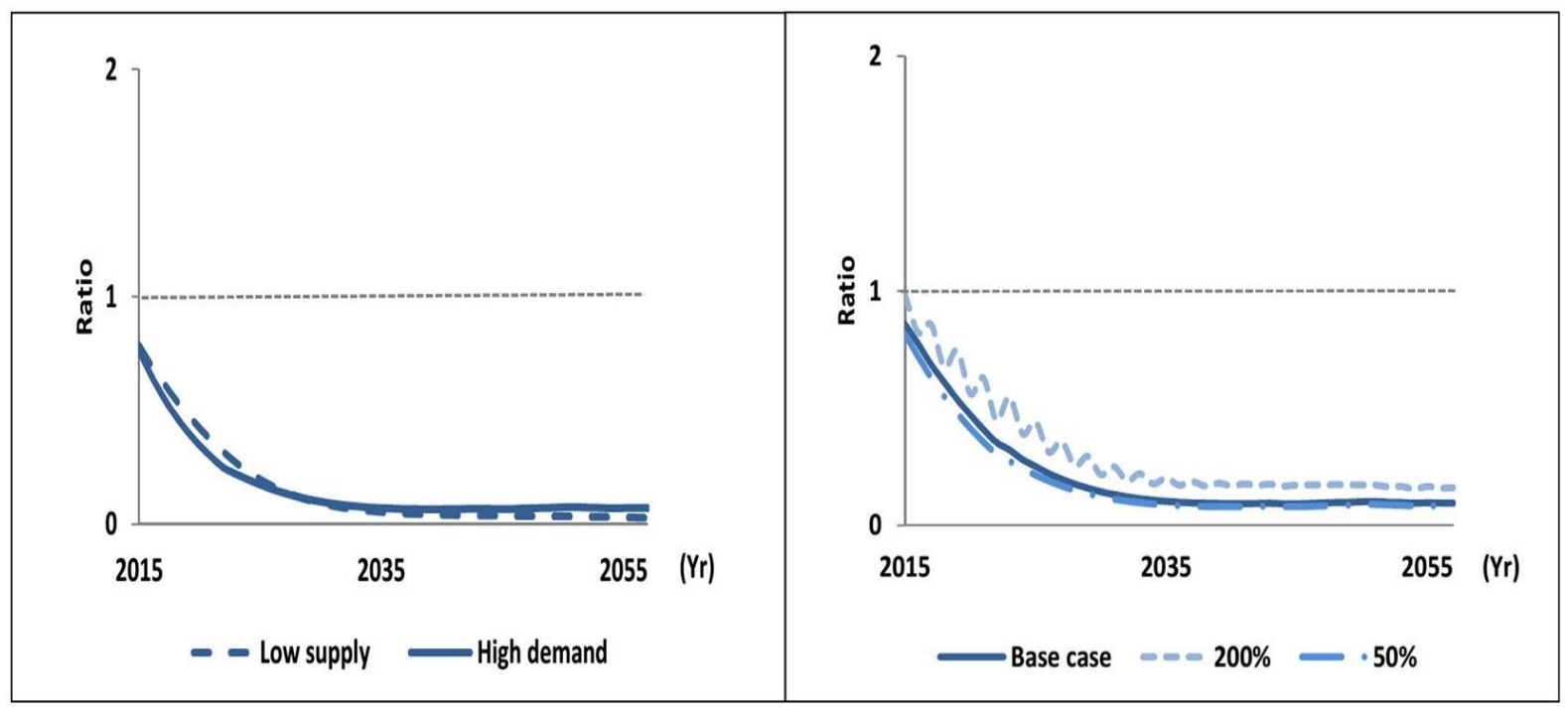

Figure 4 Extreme condition test (left) and behavior sensitivity test (right). $0.1 \%$ of global economic growth rate and zero price elasticity of indium demand are applied for low supply and high demand, respectively (left). 0.4 and 0.1 of price elasticity of indium demand are used for $200 \%$ and $50 \%$, respectively (right).

\subsubsection{Behavior sensitivity test}

Before behavior sensitivity test, a quantitative sensitivity analysis is performed to see what parameters have the most significant impact on indium demand. All parameters (total 23 and shown in Table 1) that have potential impacts on the indium 
supply and demand are analyzed. They can be grouped into two categories, i.e. parameters related to indium supply and demand and parameters included in the indium price setting process.

Table 1 Parameters for sensitivity analysis

Parameters affecting indium supply and demand
- Zinc mine production increase rate (Global economic growth rate)
- Zinc price elasticity of demand
- Zinc recycle content
CIGS PV market and b in logistic function (Equation 1) of ITO, LED, Solar PV and
- Performance ratio of CIGS technology
- Irradiation per year
- ITO recycle efficiency
PIGS module efficiency


- Indium price elasticity of demand

Model is run by varying all parameters individually by $\pm 10 \%$ from their original values. Among 23 parameters, only 13 lead to changes of greater than $1 \%$ in total indium demand over 50 years. The majority of higher impacting parameters are those involved in the solar PV market penetration and CIGS technology advancement. On the other hand, parameters involved in demand for LED and ITO are ranked low. Since majority of indium demand is due to deployment of CIGS technology in near future, it is expected that significant changes in indium demand could be made mainly by changing parameters related to the solar PV market penetration and CIGS technology advancement. For simplicity, only 13 parameters that have impacts greater than $1 \%$ are shown in Figure 5.

Among the 13 parameters, seven show inverse relationships with indium demand and the rest have positive/direct relationships. One notable point is that parameters having inverse relationships are not linearly related to indium demand (i.e. changes are non-symmetric about the vertical axis). In addition, it is observed that indium price setting mechanism (i.e. price elasticity of demand) and indium supply (i.e. zinc production increase rate and zinc recycle content) also play significant roles in determining indium demand.

Among those parameters that lead distinguishable indium demand changes, indium price elasticity of demand is chosen for behavior sensitivity test because it is the most significant one playing a role in internal feedback loop of indium demand. $200 \%$ and $50 \%$ of initial value (0.2) are assigned and simulated. Higher price elasticity of demand leads to lower demand (due to greater demand reduction) and 
consequently shows higher supply and demand ratio. Lower price elasticity of demand demonstrates the opposite trend (Figure 4, right). The above indirect structure tests demonstrate the validation of the model to implement scenarios to compare.

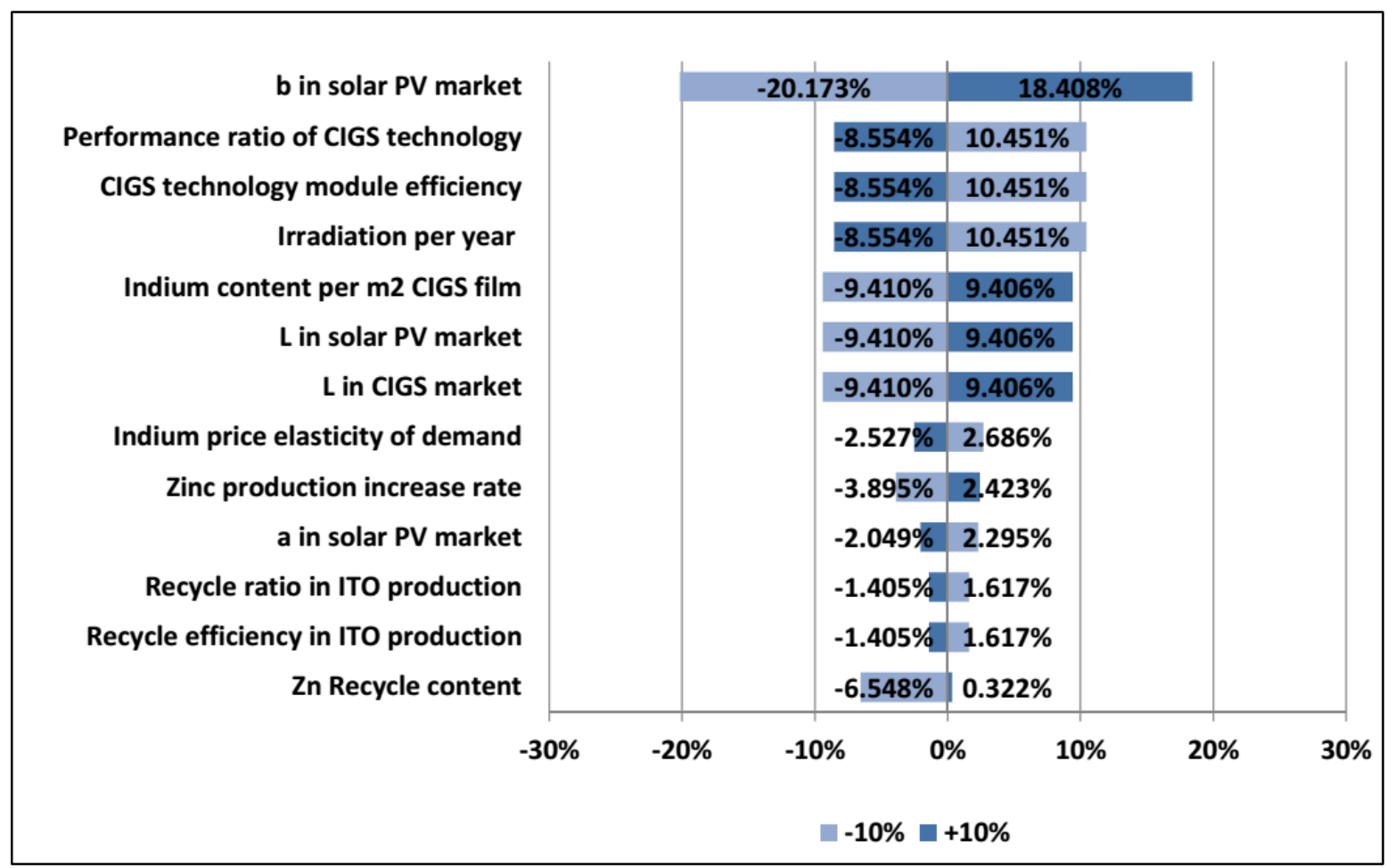

Figure 5 Sensitivity analysis of total indium demand. $\pm 10 \%$ of variations are applied to all 23 parameters and only the top 13 impacting parameters are shown. Changes due to $+10 \%$ are shown in darker blue and ones due to $-10 \%$ are shown in lighter blue. $\mathrm{L}, \mathrm{a}$, and $\mathrm{b}$ represents maximum value of market penetration curve (logistic function), time to reach the maximum value, and steepness of the curve, respectively.

\subsection{Scenario design}

After model validation, scenarios are made to see how changes on parameters lead to different dynamic behavior of indium supply and demand from 
the base scenario over the simulation time period. On the supply side, global economic growth rate eventually determines the growth rate of zinc mine production and thus indium supply. On the demand side, solar PV market penetration and technologies development in CIGS film are chosen because sensitivity analysis shows that they have the most significant impacts on the indium demand.

Beside 3\% of growth rate in 'Global economic growth rate' (base case), $2 \%$ of growth rate is chosen as an alternate case to capture more conservative case in the future. If it is assumed to be the case in the next 50 years, a smaller level of indium will be supplied each year thus demonstrate less optimistic indium supply and demand ratio.

For solar PV market penetration, an alternate scenario, which is more conservative, is considered. It is based on Annual Energy Outlook (AEO) 2015 data from Energy Information Administration (EIA). AEO 2015 expects that U.S. solar PV demand will increase from 8 TWh in 2013 to 47.1 TWh in 2040. By assuming $15 \%$ of global solar PV electricity will be generated in the U.S. (based on global solar PV capacity from IEA, 2014), the global solar PV electricity demand is calculated (denoted as 'AEO' in solar PV market column in Table 2).

Technology advancement in CIGS can significantly reduce indium demand. An alternative scenario is considered where module efficiency and indium material intensity of CIGS film are modeled to be improved as in Fthenakis (2009). Conservative, most likely, and optimistic cases in Fthenakis (2009) are applied at 10, 20 and 30 year, respectively, in this study. In addition, performance ratio of CIGS unit is assumed to increase $5 \%$ in every 15 year and reach $90 \%$ eventually. Details about parameters adapted for technology advancement are described in the Section A.2 of the supplementary material. Total 8 scenarios are made by combination of those 
control parameters and the time varying supply and demand ratios are investigated. Base scenario is set to be $3 \%$ of global economic growth rate with no technology development in 2DS solar PV market prediction. The values used for each parameter for each case are shown in Table 2.

Table 2 Values adapted to compare eight scenarios

\begin{tabular}{|r|c|c|}
\hline \multicolumn{1}{|c|}{ Control } & Base case & Alternative case \\
\hline Indium supply growth rate & Historic data & Conservative Assump. \\
\hline \begin{tabular}{|r|c|}
\hline Golabal economic growth rate \\
Generated electricity
\end{tabular} & $3 \%$ & $2 \%$ \\
\hline Technology advancement & 4,000 TWh $^{*}$ & 608 TWh $^{*}$ \\
\hline Module efficiency & No & Yes \\
\hline Material intensity & $4.2 \mathrm{~g} / \mathrm{m}^{2^{*}}$ & $16.3 \%{ }^{*}$ \\
\hline Performance ratio & $80 \%{ }^{*}$ & $2.1 \mathrm{~g} / \mathrm{m}^{2^{*}}$ \\
\hline
\end{tabular}

*indicate the values in 2050.

\section{Results}

The simulation time period is set to be 50 years (2008-2047). This is selected based on data availability and in agreement with similar dynamic MFA studies. This time period covers the market saturation point of both LED and solar PV as well as the phase-out of LCD technology. Before analyzing scenarios made in previous section, some quantitative studies regarding predictions on indium supply/demand are also performed. These correlational studies may not be as accurate as outputs from the real system but may be helpful in giving estimate and suggesting the overall 
trend at the least.

4.1. Indium supply and demand

Shortage of indium occurs when the demand exceeds the supply. Model results indicate that even under favorite case (base case) of indium supply, that is, economic growth rate of $3 \%$, growth of indium demand overwhelmingly exceeds growth of zinc mine production thus an indium supply shortage will occur in a short time period. The annual supply and demand ratio under different scenarios are explored in details and the results are compared with literature in the following Sections (4.2. and 4.3).

It is interesting to see how different applications contribute to the total indium demand over time. Figure 6 shows the breakdown of total indium demand from each application in the base scenario over the simulation period. It can be seen that indium demand is mainly driven by CIGS market penetration, which dominates after 14 years. This is expected since LCD market is already saturated so the growth rate is much slower than CIGS market.

On the other hand, the other emerging demand, LED market, does not present a significant impact on indium demand compared to other two demands even if its market dramatically expands in next decade. LED market contributes no more than $4 \%$ of annual indium demand during entire simulation period. Therefore, future indium demand will most likely be dominated by solar PV market, especially CIGS technology, as long as solar PV market grows as IEA predicted and other impacts on the market growth such as political or economic issues are in favor of supporting the solar PV market prediction. One noteworthy point is that annual indium demand rebounds around Year 2045 (Figure 6 bottom). This is because current solar PV systems will begin to enter end of life and need to be replaced. 
Shortage of supply will drive up commodity price, which in turn will affect demand. The total demand of indium during the simulation period can be reduced by $32 \%$ after including price and demand relationship of indium. Even with this demand loss, longer term supply shortage cannot be avoided in the base scenario.
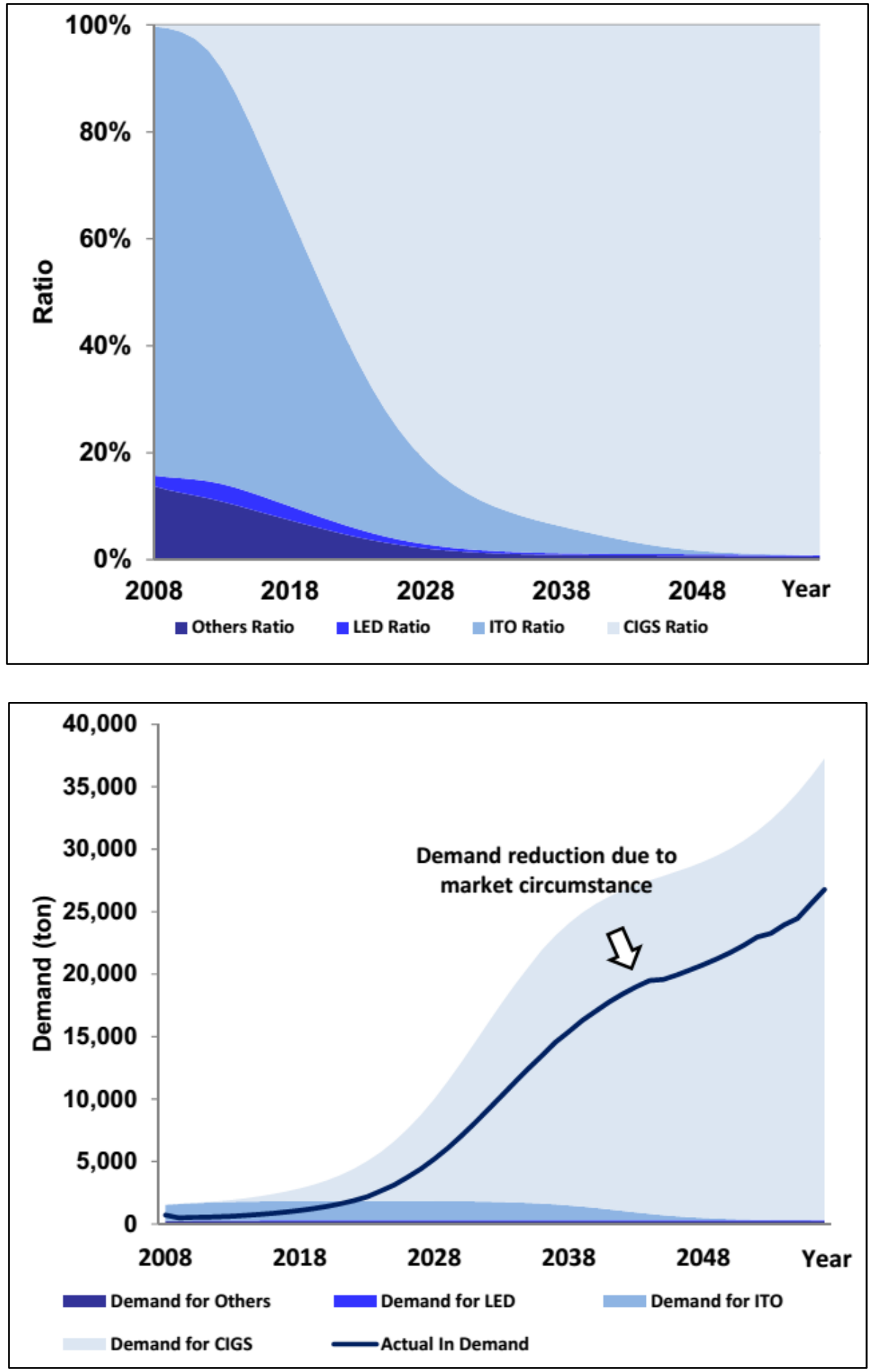
Figure 6 Annual indium demand (base scenario). The change in contribution to total indium demand per each technology (top) and annual indium demand change from each demand source with demand reduction due to market condition (bottom)

\subsection{Scenario analysis}

Table 3 shows the scenarios considered and the corresponding supply and demand balance (shown as the ratio between supply and demand) over time. Shortage occurs when the ratio is below 1 .

Table 3 Indium supply/demand ratio comparisons under different scenarios

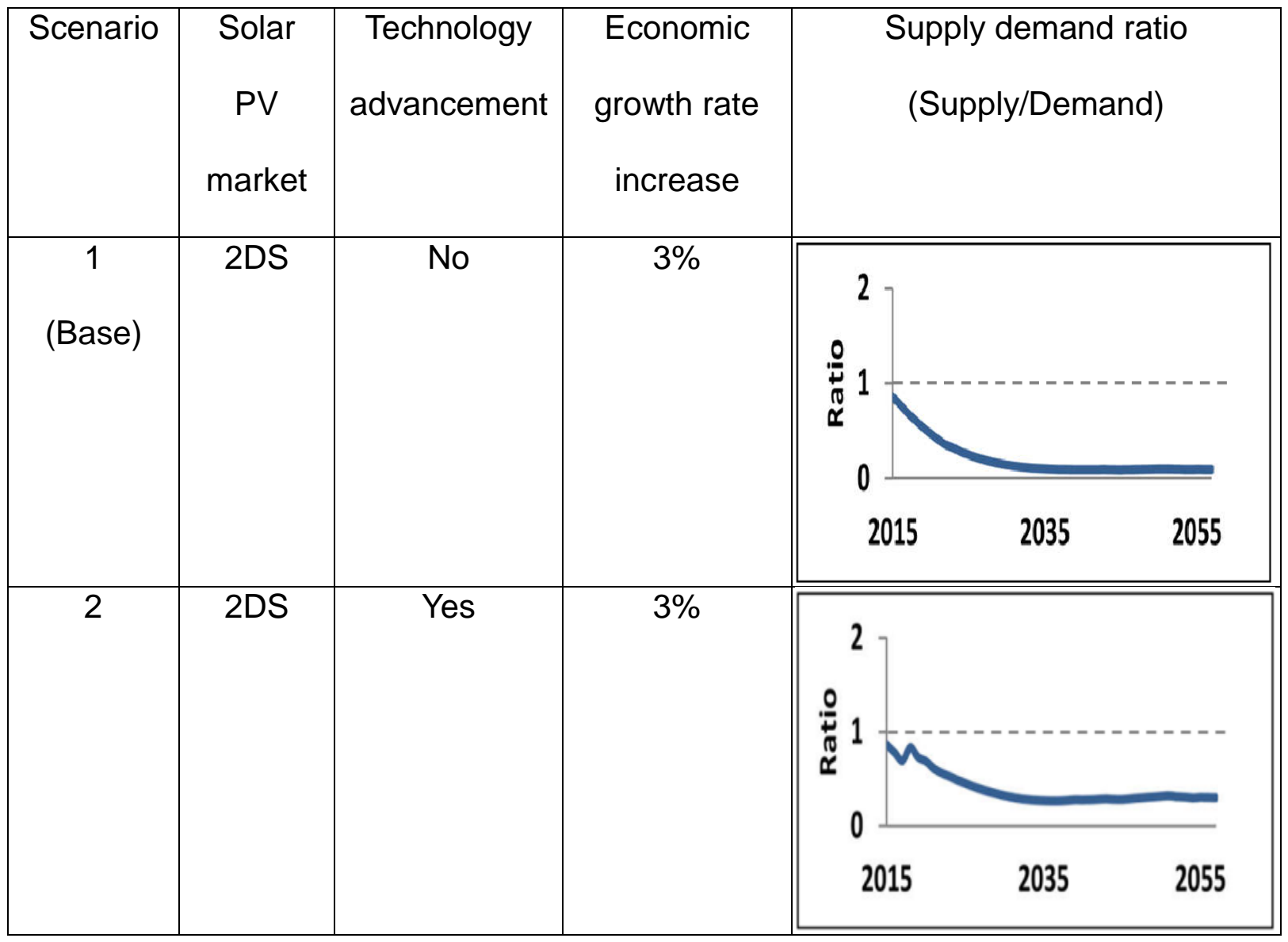




\begin{tabular}{|c|c|c|c|c|c|c|}
\hline 3 & AEO & No & $3 \%$ & 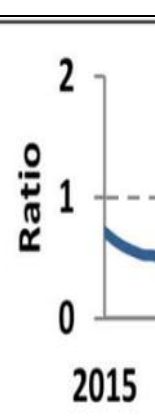 & 2035 & 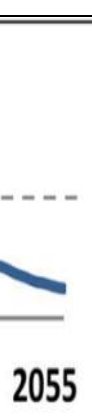 \\
\hline 4 & AEO & Yes & $3 \%$ & $\left.\begin{array}{c}2 \\
0 \\
0 \\
0 \\
0 \\
0 \\
0 \\
0 \\
015\end{array}\right]$ & 2035 & $\overline{2055}$ \\
\hline 5 & 2DS & No & $2 \%$ & 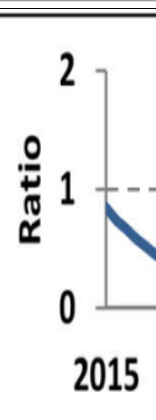 & 2035 & 2055 \\
\hline 6 & 2DS & Yes & $2 \%$ & 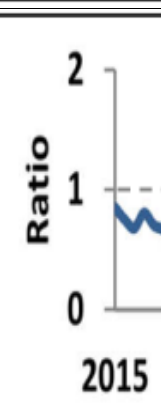 & 2035 & 2055 \\
\hline 7 & AEO & No & $2 \%$ & 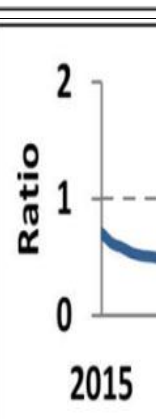 & 2035 & 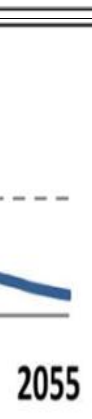 \\
\hline
\end{tabular}




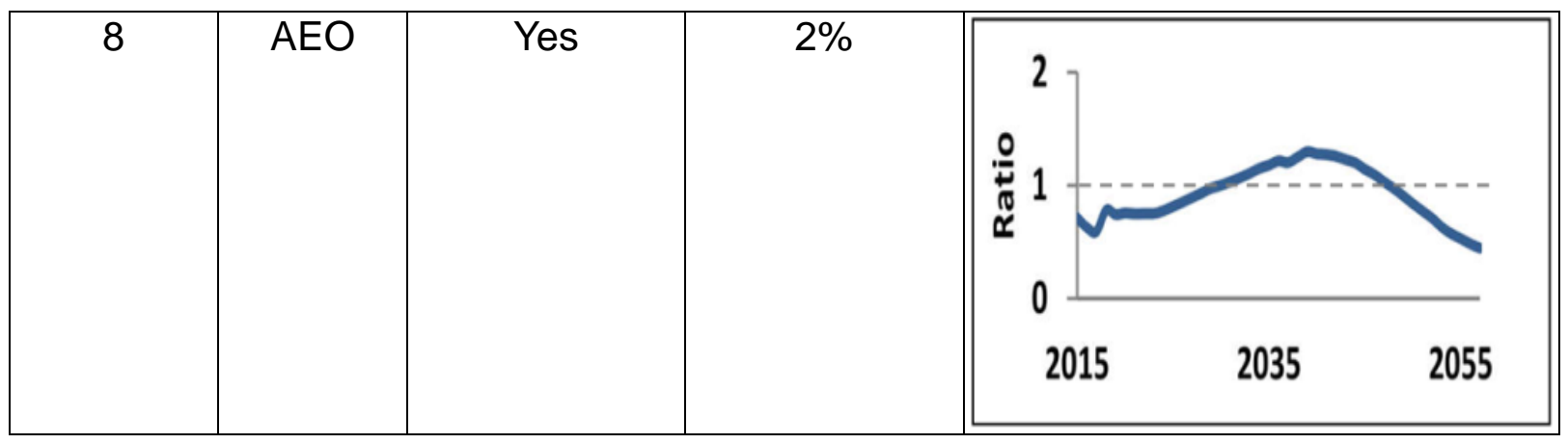

Although all eight scenarios show supply shortage in short term period, scenarios 4 and 8 show improved supply and demand balance in the middle of simulation period. These two scenarios correspond to conservative projection on solar PV penetration while significant advancement on CIGS technology. Even in these two scenarios, however, toward the end of simulation period there could be indium supply shortage. It should be noted that, however, these two scenarios may not be realistic because it is generally expected that technology advancement will lead to cost reduction and increased market penetration.

For other scenarios, indium supply shortage persists over the time period simulated. These include all scenarios with aggressive projection on solar PV market share, that is, 2DS scenario. Technology development and increasing zinc mine production could alleviate the shortage to some degree but cannot solve the issue completely. With conservative solar PV market projection, it seems that technology development plays a more important factor than growth of zinc mine production (scenarios 3 versus 8).

As suggested by sensitivity analysis, solar PV market penetration has the largest effect on the results. Similar results are observed from scenario analysis. Overall, in the scenarios with solar PV market penetration based on the EIA data, relatively well balanced supply and demand is observed when compared to the 
scenarios with 2DS projection. Since zinc demand is de-coupled with indium demand, moderate increase of indium demand due to CIGS will not drive off the balance between supply and demand. Rapid expansion of CIGS market, however, such as in 2DS scenarios outruns the growth of zinc mining production, breaks the supply and demand balance and results in significant shortage of indium.

\subsection{Comparison with previous researches}

It is interesting to compare the results from this study to those reported in the literature. Since no research analyzed indium supply and demand balance, only indium demand obtained in this study is compared to the results from previous researches (Figure 7). Annual indium demand (not supply and demand ratio) from selected scenarios (1, 4, 5 and 6 from Table 3$)$, are plotted along with demand projection in the literature. Because of differences in the time frame, results from the literature are only plotted in some specific years.

Indium demand calculations from previous studies show large variations due to different scenarios considered and assumptions made. Among them, the result from Moss et al. (2011) has the lowest indium demand, because only PV installation within European Union (EU) was included and CIGS technology was assumed to account for only $5 \%$ of total solar PV market by 2030. US DOE (2011) calculations are based on much higher CIGS market share but higher module efficiency was assumed. Zuser and Rechberger (2011) only considered photovoltaic industry in their indium demand analysis. They developed three different scenarios based on assumptions in module efficiency, layer thickness, and material utilization rate in production process. Although they only considered demand from PV, higher percentage of solar PV electricity in power generation was assumed. Different from 
other researches, Zimmerman (2013) included secondary flow (end of life recycling) of indium in the demand calculation.

More recently, Stamp et al. (2014) analyzed indium demand from CIGS under several energy scenarios. In their conservative scenario i.e. solar PV only accounts for less than $1 \%$ of total energy generation in 2050 as projected by IEA in 2004 , very low indium demand is projected. A much higher indium demand is projected in the most aggressive scenario where PV produces more than $17 \%$ of total electricity in 2050. Although this is much higher than what is projected in 2DS scenario adopted in this study (i.e. 10\%), the indium demands from Scenarios 1 and 5, which are based on 2DS scenario, are higher than projection in Stamp et al. (2014). This is because estimation from Stamp et al. (2014) accounted technological progress in the reference scenario whereas scenarios 1 and 5 in this study do not include technical advancement in CIGS film. The higher demand in scenario 1 than 5 attributes to the higher supply and thus reduced price.

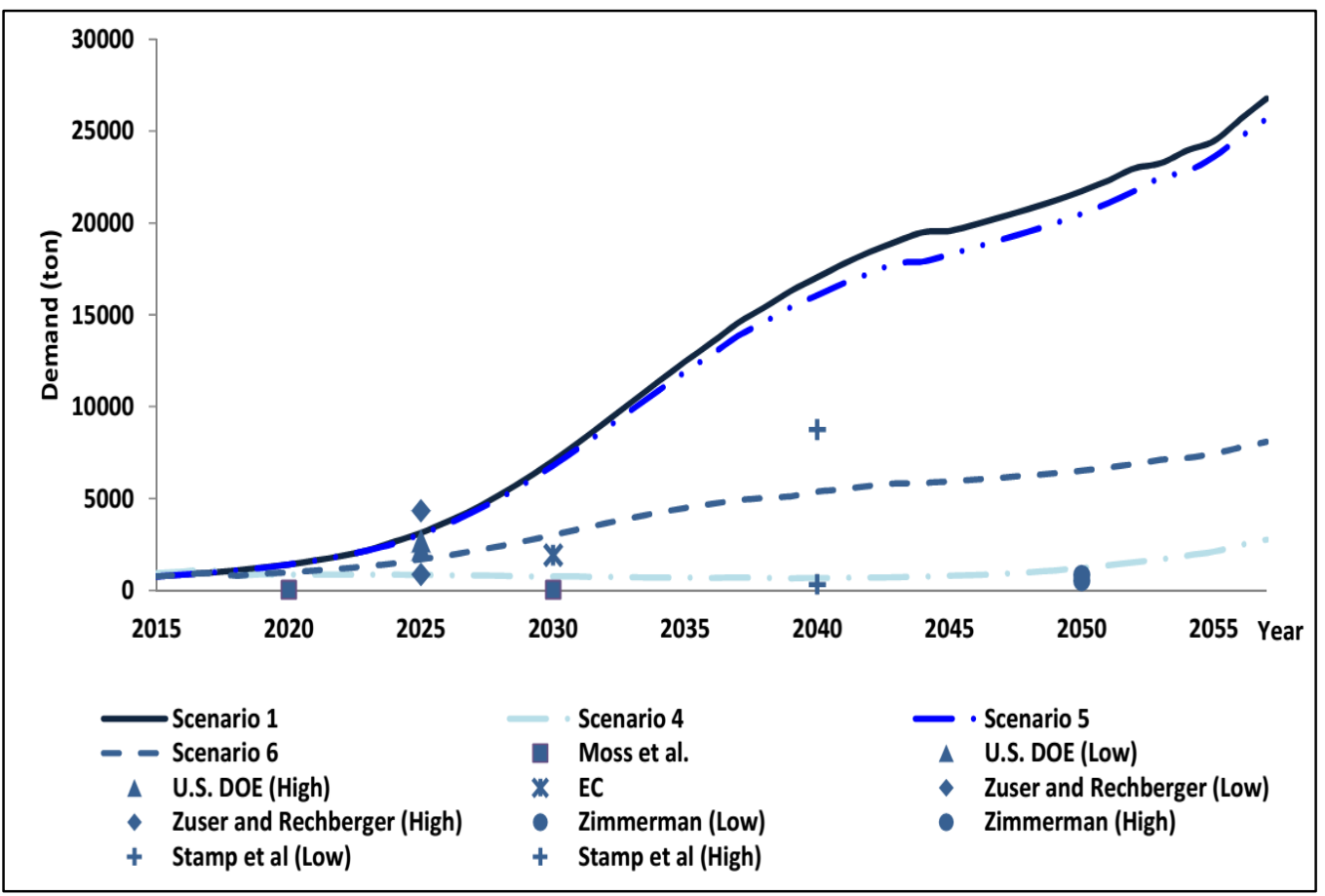


Figure 7 Results comparison with past literature. Indium demand trends in selected four scenarios (1-base, 4, 5 and 6) are compared with indium demand studied in previous studies. For simplicity, data from Zuser and Rechberger and Stamp et al. are plotted only at the middle of the simulation period.

\section{Discussion}

Explaining behavior of future supply and demand of a material is not an easy task because of complexities imbedded in both supply and demand. It is even more complicated in the case of indium because its supply is dominated by other material's (i.e. zinc) demand. This research has some advantages by including more variables that may impact on indium demand and supply, in particular price elasticity of material demand along with other factors. Although SD model developed in this research have those merits, there are still room for improvement in the future study since accuracy or reliability of simulation result does rely on the complexity and detail of the system included in the model.

\subsection{Indium supply}

In this model, indium supply is exclusively from zinc mining. Currently recovering indium from post-consumer products is not economically viable given the indium price and material intensity in consumer products, and this may not change in the foreseeable future. For example, with current indium price at $\$ 745$ per $\mathrm{kg}$, considering current indium material intensity in CIGS film, the worth of indium is only $\$ 3.1 / \mathrm{m}^{2}$. This number may decrease if the material intensity decreases by technology development (assuming that indium price does not hike rapidly).

However, producing primary indium from other ores such as sulfidic lead, tin, 
copper and iron (Hagelüken and Meskers, 2010) as well as past refining residues may become viable as shortage of indium drives up price. According to the research done by Stamp et al. (2014), some mining sites recently began to explore the feasibility of indium production from other materials.

In addition, one of the variables that determine the amount of indium supply, i.e. operation of indium circuit (nominal indium concentration), can be improved. Indium concentration varies by zinc mine location and types of the ores. According to the report by Moss et al. (2011), Peruvian and Bolivian zinc concentrate have relatively richer indium content (187 ppm and 630 ppm, respectively). Some Chinese zinc mines have indium content as high as 1,000 ppm (Gu et al., 2006). Increased indium price due to supply shortage may lead the sites with richer indium concentration to expand indium circuits. To make it more complicated, any new installation requires long lead time and decisions have to be made based on long term prediction while considering environmental and political issues.

\subsection{Indium demand}

As sensitivity and scenario analysis suggested projection on solar PV market penetration has significant effects on indium demand. It might be beneficial to consider other scenarios and projections. In addition, it has been seen that price elasticity of demand could affect indium demand to some degree. In this model, price elasticity of indium demand is assumed to be a constant for all technologies and stay constant over time. Unfortunately neither of these is true in reality. For example, the material cost of indium in LCD panel only occupies $1 \%$ of total LCD price (US SEC, 2012) and the manufacturers have the option to pass the increased material cost to consumers. Therefore, the impact of indium price volatility due to the demand 
increase might be negligible to LCD manufacturers. This may not be the case for LED and CIGS as they are trying to gain market share against existing technologies.

Another factor that may influence on indium demand is substitute. Currently, there are not competitive materials that show similar technical performance with indium at comparable price. This leads price volatility of indium when it is in the shortage of supply. However, if substitutable material emerges in the market drastic price change may be buffered. In the longer term, technical and economic competitiveness of the new material will drive up its market share and eventually decrease indium demand. For example, there are some new materials being developed as a replacement for ITO, and one of them is graphene (Geim and Novoselov, 2007).

\section{Conclusion}

This research develops a system dynamics model to investigate the behavior of supply and demand of indium under different clean energy technology deployment scenarios. Compared with published studies on indium material flows, this study takes a broader perspective by considering 1) competitive demands of indium from technologies (i.e. flat panel display manufacturing, CIGS thin film PV, and LED lighting) at different growth stage; 2) effect of primary zinc production and zinc demand in indium supply as indium is a by-product of zinc refining; and 3) price elasticity of both zinc and indium.

The model suggests annual indium demand will be dominated by CIGS PV technology in near future. Quantitative sensitivity analysis indicates that parameters associated with CIGS technology advance and market penetration are among the most influential on indium demand. Furthermore, annual supply and demand ratio is 
analyzed under different scenarios. Increased indium price due to high demand results in demand reduction to some extent but supply shortage in longer term cannot be avoided under current market prediction. Technology advancement may help alleviating the supply shortage risk to some degree. More conservative PV market projection, decreased material intensity, and increased zinc production can contribute more to well-balanced supply and demand in longer term.

\section{Acknowledgements}

This work is supported by the National Science Foundation under Grant No. 1336534 and the Critical Materials Institute, an Energy Innovation Hub funded by the U.S. Department of Energy, Office of Energy Efficiency and Renewable Energy, Advanced Manufacturing Office. Any opinions, findings, and conclusions or recommendations expressed in this material are those of the authors and do not necessarily reflect the views of the National Science Foundation and the U.S. Department of Energy.

\section{References}

Barlas, Y.1996. Formal aspects of model validity and validation in system dynamics. System Dynamics Review 12(3): 183-210. DOI: 10.1002/(SICI)10991727(199623)12:3<183::AID-SDR103>3.0.CO;2-4. 
Bayus, B. L. 1998. An analysis of product lifetimes in a technologically dynamic industry. Management Science 44 (6): 763-775. DOI:10.1287/mnsc.44.6.763.

Bicanová ,K., Z. Wittlingerov, J. Dvorák, and M. Zimová. 2015. The material flows of lead in the Czech Republic. Resources, Conservation and Recycling 98: 1-8. DOI: 10.1016/j.resconrec.2015.02.001

BP (British Petroleum). 2013. BP Statistical Review of World Energy. London: British Petroleum.

Brunner, P.H. and H. Rechberger. 2004. Practical handbook of material flow analysis. Boca Raton - USA: CRC Press LLC

Buchner, H., D. Laner, H. Rechberger, and J. Fellner. 2014. In-depth analysis of aluminum flows in Austria as a basis to increase resource efficiency. Resources, Conservation and Recycling 93: 112-123. DOI: 10.1016/j.resconrec.2014.09.016

Burgess L. 2007. Indium Demand - Our Indelible Interest in Indium. http://www.wealthdaily.com/articles/indium-demand-production/3499. Accessed 20 February 2016

Cenergy Maxpower. 2014. Market share of thin film technologies. www.cenergymaxpower.com/introduction-solar-pv-modules/. Accessed 10 January. 2015. 
Dimmler, B. 2012. CIGS and CdTe based thin film PV modules, an industrial revolution. 2012 38th IEEE Photovoltaic Specialists Conference (PVSC) : 002494-002499. DOI:10.1109/PVSC.2012.6318101.

EC (European Commission). 2010a. Critical raw materials for the EU report of the Ad-hoc Working Group on Defining Critical Raw Materials. Brussels: European Commission.

EC (European Commission). 2010b. Critical raw materials for the EU - Annex $V$ to the report of the Ad-hoc Working Group on Defining Critical Raw Materials. Brussels: European Commission.

Edison Investment. 2011. Indium and gallium overview. www.edisoninvestmentresearch.com/sectorreports/IndiumGalliumOverview07 1011.pdf. Accessed 11 February 2015.

EIA (Energy Information Administration). 2015. Annual energy outlook 2015 with projections to 2040. Washington DC: Energy Information Administration.

Fraunhofer Institute. 2012. Photovoltaics report. www.ise.fraunhofer.de/de/downloads/pdf-files/aktuelles/photovoltaicsreport.pdf. Accessed 14 January 2015.

Fthenakis, V. 2009. Sustainability of photovoltaics: The case for thin-film solar cells. 
Renewable and Sustainable Energy Reviews 13 (9): 2746-2750. DOI:10.1016/j.rser.2009.05.001.

Geim, A. K. and K. S. Novoselov. 2007. The rise of graphene. Nature Materials 6 (3): 183-191. DOI:10.1038/nmat1849.

Glöser, S., M. Soulier, and L. A. Tercero Espinoza. 2013. Dynamic analysis of global copper flows. Global stocks, postconsumer material flows, recycling indicators, and uncertainty evaluation. Environmental Science \& Technology 47 (12): $6564-6572$.

Goonan, T.G. 2012. Materials flow of indium in the United States in 2008 and 2009 (1377). Reston, VA, USA: U.S. Geological Survey.

Gu, C. , S. Huang, H. Cao, H. Tan, X. Liang, Z. Jiang. 2006. Nandan Country Jilang Indium Manufacturing Co.,Ltd Integrated Indium and Zinc Recovery Project Environmental Impact Statement. Guangxi. China: Scientific Research Academy of Guangxi Environmental Protection.

Hagelüken C and CEM Meskers. Complex life cycles of precious and special metals. In Strüngmann Forum Report: Linkages of Sustainability, Graedel TE, van der Voet E (eds). MIT Press: Cambridge, MA, USA, 2010. 
Hatayama, H., H. Yamada, I. Daigo, Y. Matsuno, and Y. Adachi. 2007. Dynamic substance flow analysis of aluminum and its alloying elements. Materials Transactions 48 (9): 2518-2524. DOI:10.2320/matertrans.MRA2007102.

Houari, Y., J. Speirs, C. Candelise, and R. Gross. 2014. A system dynamics model of tellurium availability for CdTe PV. Progress in Photovoltaics: Research and Applications 22 (1): 129-146. DOI:10.1002/pip.2359.

Huang, C.L., J. Vause, H.W. Ma, and C.P. Yu. 2012. Using material/substance flow analysis to support sustainable development assessment: A literature review and outlook. Resources, Conservation and Recycling 68: 104-116. DOI:10.1016/j.resconrec.2012.08.012.

IEA (International Energy Agency). 2014. Technology Roadmap: Solar Photovoltaic Energy. Paris: International Energy Agency.

IZA (International zinc association). 2011a. Zinc recycling: closing the loop. www.zinc.org. Accessed 14 February 2015.

IZA (International zinc association). 2011b. Zinc recycling: material supply. www.zinc.org. Accessed 14 February 2015.

Kaiser, J.A. 2015. Kaiser research online. http://www.kaiserbottomfish.com/s/Expresses.asp?ReportID=703881. Accessed 17 February 2016. 
Kleijn, R., R. Huele, and E. van der Voet. 2000. Dynamic substance flow analysis: The delaying mechanism of stocks, with the case of PVC in Sweden. Ecological Economics 32 (2): 241-254. DOI:10.1016/S0921-8009(99)00090-7.

Kumar, S and B. Sarkar. 2013. Design for reliability with weibull analysis for photovoltaic modules. International journal of current engineering and technology 3 (1): 129-134.

Leal-Ayala, D. R., J. M. Allwood, E. Petavratzi, T. J. Brown, and G. Gunn. 2015. Mapping the global flow of tungsten to identify key material efficiency and supply security opportunities. Resources, Conservation and Recycling 103: 19-28. DOI:10.1016/j.resconrec.2015.07.003

Matsuno, Y., T. Hur, and V. Fthenakis. 2012. Dynamic modeling of cadmium substance flow with zinc and steel demand in Japan. Resources, Conservation and Recycling 61: 83-90. DOI:10.1016/j.resconrec.2012.01.002.

McKinsey \& Company. 2012. Lighting the way: Perspectives on the global lighting market. New York City, NY, USA: McKinsey \& Company.

Melo, M. T. 1999. Statistical analysis of metal scrap generation: The case of aluminum in Germany. Resources, Conservation and Recycling 26: 91-113. DOI:10.1016/S0921-3449(98)00077-9. 
Moss, R. L., E. Tzimas, H. Kara, P. Willis, and J. Kooroshy. 2011. Critical metals in strategic energy technologies. Assessing rare metals as supply-chain bottlenecks in low-carbon energy technologies. Petten, Netherlands: Institute for Energy and Transport (IET).

Morf, L. S., A. M. Buser, R. Taverna, H.-P. Bader, and R. Scheidegger. 2008. Dynamic substance flow analysis as a valuable risk evaluation tool - A case study for brominated flame retardants as an example of potential endocrine disrupters. CHIMIA International Journal for Chemistry 62 (5): 424-431. DOI:10.2533/chimia.2008.424.

Müller, E., L. M. Hilty, R. Widmer, M. Schluep, and M. Faulstich. 2014. Modeling metal stocks and flows: A review of dynamic material flow analysis methods. Environmental Science \& Technology 48 (4): 2102-2113. DOI: 10.1021/es403506a.

Nakajima, K., K. Yokoyama, K. Nakano, and T. Nagasaka. 2007. Substance flow analysis of indium for flat panel displays in Japan. Materials Transactions 48 (9): 2365-2369. DOI:10.2320/matertrans.MAW200702.

NRCan (Natural Resource Canada). 2009. Canadian mineral yearbook: Zinc 2009. Ottawa, Ontario, Canada: Natural Resource Canada. 
Nicholson W. and C. Snyder. 2011. Chapter 2: Mathematics of Microeconomics. In Micro economic theory: Basic principles and extensions. 11th edition. Mason, $\mathrm{OH}$ : South western.

Niels J., M. Stucki, R. Frischknecht, and ESU-services Ltd., Uster, 2009, Ecoinvent report No. 6 XII Photovoltaic, Swiss Centre for Life Cycle Inventories.

Polinares. 2012. Fact Sheet: Indium. www.polinares.eu/docs/d21/polinares_wp2_annex2_factsheet5_v1_10.pdf. Accessed 31 January 2015.

Pruyt, E. and TU Delft: Technology, policy and management: Multi actor systems. 2010. Scarcity of minerals and metals: A generic exploratory system dynamics model. System Dynamics Society.

Saysel, A. K., and Barlas, Y. 2001. A dynamic model of salinization on irrigated lands. Ecological Modelling 139(2-3): 177-199. DOI: 10.1016/S03043800(01)00242-3.

Semenza P. 2010. A new chapter for the display market. http://informationdisplay.org/IDArchive/2010/MayJune/DisplayMarketplaceAN ewChapterfortheDisplay.aspx. Accessed 13 January 2015.

Stamp, A., P. A. Wäger, and S. Hellweg. 2014. Linking energy scenarios with metal demand modeling-The case of indium in CIGS solar cells. Resources, 
Conservation and Recycling 93: 156-67.

DOI:10.1016/j.resconrec.2014.10.012.

Sterman, J. D. 2000. Business dynamics: systems thinking and modeling for a complex world. Boston: Irwin/McGraw-Hill.

Stuermer, M. 2013. Industrialization and the demand for mineral commodities. SSRN Electronic Journal. http://doi.org/10.2139/ssrn.2364309

Tani D. 2015. The world economy - 50 years of near continuous growth. http://www.worldeconomics.com/papers/Global\%20Growth\%20Monitor_7c66f fca-ff86-4e4c-979d-7c5d7a22ef21.paper. Accessed 17 February 2016.

US DOE (U.S. Department of Energy). 2011. Critical materials strategy. Washington, DC: U.S. Department of Energy.

USGS (U. S. Geological Survey). 2008. Minerals commodity summaries: Indium. 2008. Reston, VA, USA: U.S. Geological Survey.

USGS (U. S. Geological Survey). 2009a. Minerals commodity summaries: Indium. 2009. Reston, VA, USA: U.S. Geological Survey.

USGS (U. S. Geological Survey). 2009b. Minerals commodity summaries: Zinc. 2009. Reston, VA, USA: U.S. Geological Survey. 
USGS (U. S. Geological Survey). 2009c. Minerals year book: Indium. 2009. Reston, VA, USA: U.S. Geological Survey.

USGS (U. S. Geological Survey). 2012a. Minerals commodity summaries: Zinc. 2012. Reston, VA, USA: U.S. Geological Survey.

USGS (U. S. Geological Survey). 2012b. Minerals year book: Indium. 2012. Reston, VA, USA: U.S. Geological Survey.

USGS (U. S. Geological Survey). 2012c. Minerals year book: Zinc. 2012. Reston, VA, USA: U.S. Geological Survey.

USGS (U. S. Geological Survey). 2015. Minerals commodity summaries: Zinc. 2015. Reston, VA, USA: U.S. Geological Survey.

US SEC (U.S. Securities and Exchange Commission). 2012. Annual report of SMG indium resources $L T D$. www.sec.gov/Archives/edgar/data/1426506/000114420413019117/v336853_ 10k.htm. Accessed 20 January 2015.

Wang, M., W. Chen, and X. Li. 2015. Substance flow analysis of copper in production stage in the U.S. from 1974 to 2012. Resources, Conservation and Recycling, 105: 36-48. DOI:10.1016/j.resconrec.2015.10.012 
World Bank. 2015. Global economic prospect - Having fiscal space and using it. Washington, DC: The World Bank.

Yole development. 2012. Status of LED Industry Report. www.yole.fr/iso_upload/News/2012/PR_Status\%20of\%20the\%20LED\%20Ind ustry_YOLE\%20DEVELOPPEMENT_August2012.pdf. Accessed 4 February 2015.

Yoshimura, A., I. Daigo, and Y. Matsuno. 2013. Global substance flow analysis of indium. Materials Transactions 54 (1): 102-109.

DOI:10.2320/matertrans.M2012279.

Zeltner, C., H.-P. Bader, R. Scheidegger, and P. Baccini. 1999. Sustainable metal management exemplified by copper in the USA. Regional Environmental Change 1 (1): 31-46. DOI:10.1007/s101130050006.

Zimmermann, T. 2013. Dynamic material flow analysis of critical metals embodied in thin-film photovoltaic cells. http://elib.suub.uni-bremen.de/edocs/001035731.pdf. Accessed 15 June 2015.

Zuser, A. and H. Rechberger. 2011. Considerations of resource availability in technology development strategies: The case study of photovoltaics. Resources, Conservation and Recycling 56: 56-65. DOI:10.1016/j.resconrec.2011.09.004. 


\section{Appendix A}

\section{Supplementary material}

A.1. SD model (Section 2.4. in the main document)

A.1.1. Zinc supply and demand model (Section 2.4 .1 in the main document)

Zinc supply consists of two components, i.e. direct refining after mining ('refined zinc production') and 'recycling' from end of life product. Both contribute to the amount of annual 'zinc slab stock' as inflows. Demand for 'production of goods' is set as an outflow from 'zinc slab stock'. The 'zinc slab stock' cannot be negative in real practice. For this reason, an auxiliary variable, 'actual zinc slab stock' is introduced and minimum stock is given as 1 ton for the technical purpose. Thus, annual zinc slab stock is modeled as follows;

'Zinc Slab Stock' $=$ 'Current Zinc Stock' $+\int{ }^{\prime R e f i n e d ~ Z i n c ~ P r o d u c t i o n ' ~}+$ S'Recycling' - $\int$ 'Production of Goods'

'Actual Zinc Slab Stock' = Min ('Zn Slab Stock', 1 ton)

"Recycling" is the amount of zinc recovered from end of life products. It is assumed that the recycled content in total zinc production is $15 \%$ and it stays unchanged (IZA, 2011a). Therefore, the amount of recycling of zinc for inflow to the 'zinc slab stock' is modeled as:

'Recycling' $=$ 'Recycle Content $(15 \%)^{\prime} \times($ Recycling' + 'Refined Zinc Production') 
The 'refined zinc production' is calculated as the product of the amount of 'annual extraction' and 'refinery efficiency' (taken as $85 \%$ ). 'Zinc mine production', which is directly linked to 'annual extraction', is annual amount of zinc mined from the ground. Annual 'zinc production increase rate' is linked with 'global economic growth rate' and the relationship is well explained in the main document and Table A.2.

'Refined Zinc Production' = 'Annual Extraction' (equal to 'Zinc Mine Production') $\times$ 'Refinery Efficiency (85\%)'

'Zinc Mine Production' $=$ 'Current Mine Production' + S'Zinc Production Increase'

'Zinc Production Increase' = 'Zinc Mine Production' $\times$ 'Zn Production Increase Rate'

For the zinc demand, 'production of goods' is representative of zinc demand and is directly linked with stock variable, 'zinc annual demand'. Global economic growth contributes to the increase of 'zinc annual demand'. 'Demand loss due to price elasticity' is set to be outflow from 'zinc annual demand'.

'Zinc Annual Demand' = 'Current Zinc Demand' + $\int$ 'Demand Increase' S'Zinc Demand Losses due to Price Elasticity' 
'Demand Increase' = 'Zinc Annual Demand' $\times$ 'Global Economic Growth Rate'

A.1.2. Zinc price setting model (Section 2.4.1 in the main document)

Zinc price in this model is mainly determined by the amount of 'zinc slab stock'. The relationship between price and zinc slab stock ('effect of stock on price') is obtained through stock and price data from 2005 to 2008 (NRCan, 2009). Year-toyear change rates of price and stock are plotted and an inverse exponential relationship is drawn. The relationship is expressed in Table A.2.

With this relationship, 'zinc price' is determined by multiplying 'traders' expected zinc price' and 'effect of stock on price'.

'Zinc Price' $=$ 'Effect of Stock on Price' $\times$ 'Traders Expected Zinc Price'

The calculated 'zinc price' is compared to the 'zinc production cost' and the larger between the two is used as the 'zinc market price', which eventually impacts 'zinc demand losses due to price elasticity'. Here it is assumed that refining companies will not sell the material under their production cost. 'Zinc price elasticity of demand' is assumed to be 0.07 in this model (Stuermer, 2013). Zinc production cost is assumed to increase $3 \%$ every year to reflect global inflation (World Bank, 2015). Variables and parameters relationships in the zinc price setting model are listed in Figure A.1.

'Zinc Market Price' = Max ('Zinc Production Cost', 'Zinc Price') 
Demand' $\times$ ('Last Yr Zinc Market Price' - 'This Yr Zinc Market Price') /'Last Yr Zinc Market Price') $\times$ 'Last Yr Zn Demand'))

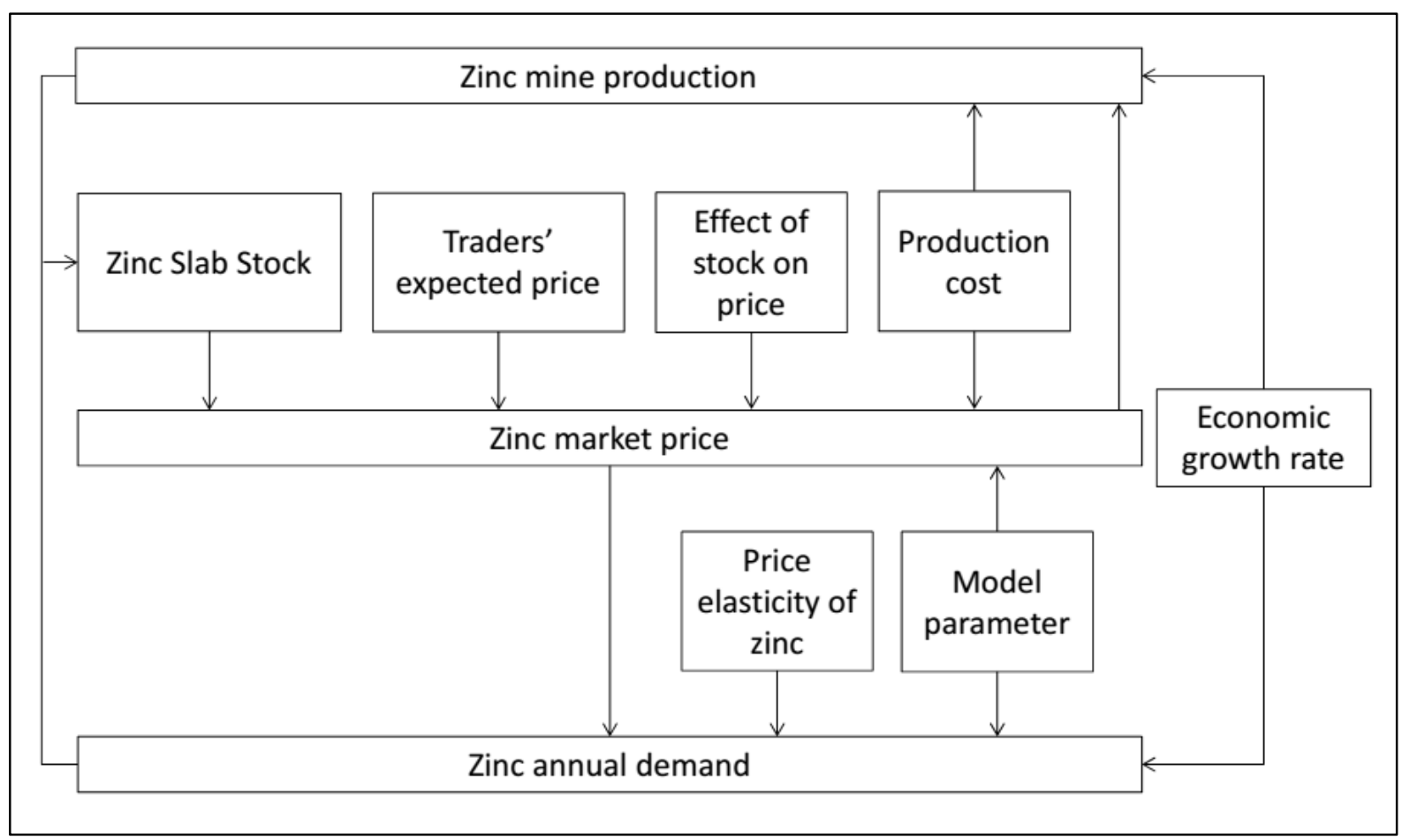

Figure A.1 Description of zinc price setting model. All names of variables and parameters are the same as for those in the stock and flow diagram (Figure 3) in main the document.

A.1.3. Indium supply and demand model (Section 2.4 .2 in the main document) 'Zinc mine production' is multiplied by 'operation of indium circuit' (nominal indium concentration) to give an amount of annual indium supply. Indium concentration varies by zinc mine location and types of the ores. For simplification, a nominal concentration is commonly used and is calculated by dividing total indium production with total zinc production. Please note this nominal concentration is not the indium concentration in the zinc ores. When indium price drops, it is likely that 
indium circuits that process residue streams with relatively lower indium concentration (proportional to indium concentration in zinc ore) will be shut down first. As a result, the nominal indium concentration will change. This change is reflected in the 'operation of indium circuit' with inverse linear relationship with supply and demand ratio assuming indium supply and demand will not affect zinc production. Considering that the current nominal indium concentration is $50 \mathrm{ppm}$, the range of possible nominal concentration is set to be from 10ppm to $100 \mathrm{ppm}$ and the nominal concentration (thus the indium supply) is selected using the linear relationship for supply-demand ratio between 0.5 and 1.5 . The relationship between the concentration and supply demand ratio is depicted in Table A.2.

'Yearly Indium Supply' = 'Current Zinc Mine Production' $\times$ 'Initial Nominal Indium Concentration in Zinc Ore (50ppm)' $+\int$ 'Yearly Supply Increase'

'Yearly Supply Increase' = 'Zinc Production Increase' $\times$ 'Operation of indium circuit (Nominal Indium concentration)'

'Actual Indium Supply' = 'Indium Supply' = 'Yearly Indium Supply'

Indium in ITO demand is first calculated based on the S-curve obtained from data reported by Semenza in 2010. Then recyclable amount of indium in the sputtering process is subtracted to get 'primary demand for ITO'. Two parameters required to calculated recyclable amount of indium are 'recycle ratio' and 'recycle efficiency'. Recycle ratio represents the percentage of indium that is not deposited on the substrate during the sputtering process and recycle efficiency is how much of 
indium can actually be recycled from non-sputtered residue. They are reported as $70 \%$ and $90 \%$ in 2008, respectively (Edison Investment, 2011; USGS, 2009a; Goonan, 2012).

'Primary Demand for ITO' = 'Demand for ITO' - 'Recycle to ITO Production'

Demand for LED is simply calculated by applying S-curve obtained from the data suggested by Yole development in 2012 (Yole development, 2012).

Indium required for CIGS thin film technology is calculated in two steps. First S-curve for entire solar PV market growth is constructed using market penetration data proposed by the IEA and EIA. The two scenarios from IEA are compared in Table A.1 and only '2DS' scenario from IEA is used for this study. Among them, the portion of CIGS thin film technology is assumed to be $25 \%$ in 2050 (Stamp et al., 2014; Zuser and Rechberger, 2011) and S-curve of the technology is built based on the past market share data reported by Cenergy maxpower (Cenergy Maxpower, 2014). Using expected power generation obtained from the CIGS market penetration, indium demand for CIGS technology is calculated based on Equation 2 in the main document. Sources of the parameters used in Equation 2 are shown in Table A.2. Overall, total indium demand and primary production demand are obtained using following equations:

'Total Demand' = 'Demand for ITO' + 'Demand for LED' + 'Demand for CIGS' 'Primary Production Demand' = 'Total Demand'- 'Recycle to ITO Production' 
Table A.1 Two solar PV market scenarios from IEA

\begin{tabular}{|c|c|c|c|}
\hline Scenarios & $\begin{array}{c}\text { Target global } \\
\text { temperature rise }\end{array}$ & Strategy & $\begin{array}{c}\text { Solar PV electricity } \\
\text { generation by 2050 } \\
(\% \text { in total elec. } \\
\text { generation) }\end{array}$ \\
\hline '2DS' & $2{ }^{\circ} \mathrm{C}$ & Expand & \\
scenario & renewable energy & $4,000 \mathrm{TWh}(10 \%)$ \\
'Hi-Ren' & $2{ }^{\circ} \mathrm{C}$ & $\begin{array}{c}\text { Maxage } \\
\text { PV usage beyond } \\
\text { '2DS' scenario }\end{array}$ & 6,300 TWh (16\%) \\
\hline
\end{tabular}

A.1.4. Indium price setting model (Section 2.4 .2 in the main document) In the indium price setting model, 'actual indium demand', which presents more realistic indium demand expectation, is calculated after considering 'effect of shortage on price' and 'indium price elasticity of demand'. Inverse exponential function is obtained between indium price change and indium 'supply/demand ratio change' from the historical data (Polinares, 2012 and Burgess 2007) and used for 'effect of shortage on price'. And this is multiplied by 'traders' expected indium price' to calculate 'indium price'. The parameters used to calculate 'effect of shortage on price' is listed in Table A.2.

'Indium Price' $=$ 'Effect of Shortage on Price' $\times$ 'Traders Expected Indium Price' 
'Supply Demand Ratio Change' = $($ 'Actual In Supply' $/$ 'Actual In Demand' $) /($ Last Year Actual In Supply/Last Year Actual In Demand)

'Indium market price' is taken as the larger between the calculated 'indium price' and the 'indium production cost', assuming refining companies will not sell the material under their production cost. 'Indium market price' eventually impacts 'indium demand loss due to price elasticity'. Lost demand due to price increase is reflected in calculated 'actual indium demand'. And this 'actual indium demand' is not allowed to be negative since demand cannot be negative. 'Indium price elasticity of demand' is assumed to be 0.2 , which shows moderate price elasticity among the mineral commodities studied in Stuermer's work (Stuermer, 2013). Connections among variables and parameters in the indium price setting model are depicted in Figure A.2.

'Indium Market Price' = Max ('Indium Production Cost', 'Indium Price')

'Indium Demand Losses due to Price Elasticity' = Max (0, ('In Price Elasticity of Demand' $\times$ ('Last Yr Indium Market Price' - 'This Yr Indium Market Price') /'Last Yr Indium Market Price) $\times$ 'Last Yr Actual Indium Demand'))

'Actual Indium Demand' $=\int$ 'Demand Change' - 'Indium Demand Losses due to Price Elasticity'

'Demand Change' $=$ 'Primary Production Demand' - 'Previous Year Primary Production Demand' 


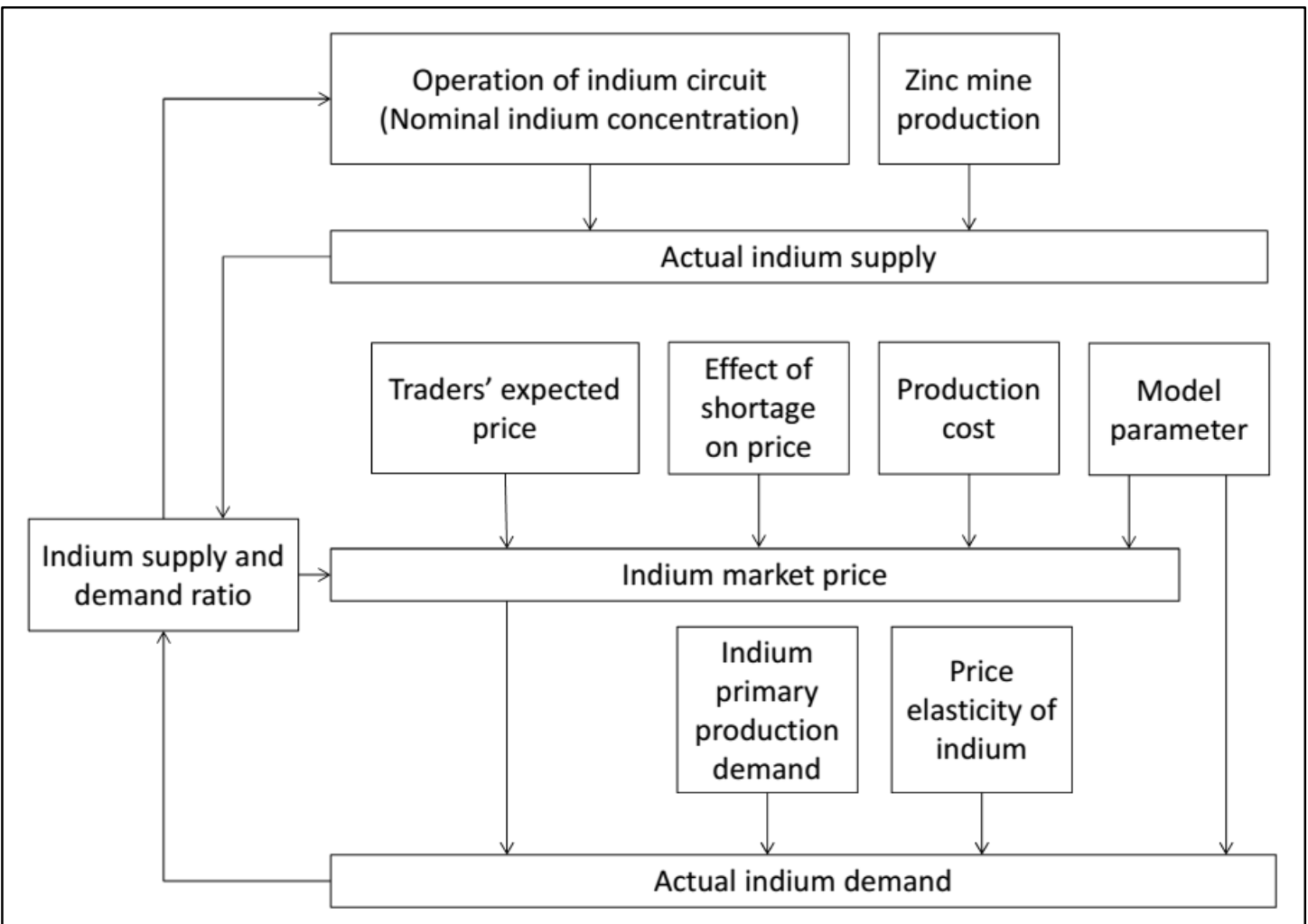

Figure A.2 Description of indium price setting model. All names of variables and parameters are the same as for those in the stock and flow diagram (Figure 3) in the main document.

\section{A.2. Model parameters}

All sources and assumptions, if necessary, for the parameter values are listed in Table A.2.

Table A.2 Parameters adapted in system dynamics modeling

\begin{tabular}{|l|l|l|}
\hline \multicolumn{1}{|c|}{ Parameter } & \multicolumn{1}{|c|}{ Value } & Source \\
\hline \hline \multicolumn{2}{|c|}{ Zinc } \\
\hline Current reserve & 250 million ton & IZA, 2011b \\
\hline Current reserve base & 480 million ton & USGS, 2009b \\
\hline
\end{tabular}




\begin{tabular}{|c|c|c|}
\hline Current zinc slab stock & 764,000 ton & NRCan, 2009 \\
\hline Zn production increase rate & $\begin{array}{l}\text {. 'economic growth } \\
\text { rate' if 'Zn market } \\
\text { price' } \geq \text { 'Zn } \\
\text { production cost' } \\
.0 \% \text { otherwise }\end{array}$ & $\begin{array}{l}\text { Kaiser, } 2015 \text { and Tani, } \\
2015\end{array}$ \\
\hline $\mathrm{Zn}$ refinery efficiency & $85 \%$ & $\begin{array}{l}\text { Calculated using data in } \\
\text { NRCan, } 2009\end{array}$ \\
\hline $\begin{array}{l}\text { Global economic growth } \\
\text { rate }\end{array}$ & $3 \%, 2 \%$ & $\begin{array}{l}\text { World Bank } 2015 \text { and IMF } \\
2015\end{array}$ \\
\hline $\begin{array}{l}\text { Global average inflation } \\
\text { rate }\end{array}$ & $3 \%, 2 \%$ & $\begin{array}{l}\text { World Bank } 2015 \text { and IMF } \\
2015\end{array}$ \\
\hline Current zinc demand & 11.437 million ton & NRCan, 2009 \\
\hline Current mine production & 11.690 million ton & NRCan, 2009 \\
\hline Price elasticity of demand & 0.07 & Stuermer, 2013 \\
\hline Effect of stock on price & $\begin{array}{l}\text { 'Yearly zinc price } \\
\text { change rate' }=6.7447 \\
{ }^{*} \exp \left(-1.781^{*} \text { Yearly }\right. \\
\text { zinc stock change } \\
\text { rate') }-0.13\end{array}$ & NRCan, 2009 \\
\hline $\begin{array}{l}\text { Current traders' expected } \\
\text { price }\end{array}$ & $\$ 1874.70 /$ ton & NRCan, 2009 \\
\hline $\begin{array}{l}\text { Current average production } \\
\text { cost }\end{array}$ & $\$ 1787$ / ton & Gu et al., 2006 \\
\hline
\end{tabular}




\begin{tabular}{|c|c|c|}
\hline \multicolumn{3}{|l|}{ Indium } \\
\hline $\begin{array}{l}\text { Initial nominal indium } \\
\text { concentration in zinc ore }\end{array}$ & $0.005 \%$ & Polinares, 2012 \\
\hline Current indium demand & 1,535 ton & $\begin{array}{l}\text { USGS, 2009a and } \\
\text { Assumption }\end{array}$ \\
\hline $\begin{array}{l}\text { Recycle efficiency in ITO } \\
\text { production }\end{array}$ & $90 \%$ & Goonan, 2012 \\
\hline $\begin{array}{l}\text { Recycle ratio in ITO } \\
\text { production }\end{array}$ & $70 \%$ & Goonan, 2012 \\
\hline $\begin{array}{l}\text { Current indium demand in } \\
\text { ITO }\end{array}$ & 1289 ton / year & US SEC, 2012 \\
\hline $\begin{array}{l}\text { Current indium demand in } \\
\text { LED }\end{array}$ & 30.7 ton / year & $\begin{array}{l}\text { Assumption (All } \\
\text { semiconductor usage are } \\
\text { dedicated to LED) }\end{array}$ \\
\hline $\begin{array}{l}\text { Current indium content in } \\
\text { CIGS film }\end{array}$ & $4.2 \mathrm{~g} / \mathrm{m}^{2}$ & $\begin{array}{l}\text { Raugei et al., } 2007 \text { and } \\
\text { Niels et al., } 2009\end{array}$ \\
\hline $\begin{array}{l}\text { Current thickness of CIGS } \\
\text { film ( 10 yrs })\end{array}$ & $1.6 \mathrm{um}$ & Fthenakis, 2009 \\
\hline \multicolumn{3}{|l|}{$\begin{array}{l}\text { Future thickness of CIGS } \\
\text { film (10 yrs } \sim)\end{array}$} \\
\hline Conservative & $1.2 \mathrm{um}$ & Fthenakis, 2009 \\
\hline Most likely & $1.0 \mathrm{um}$ & Fthenakis, 2009 \\
\hline Optimistic & $0.8 \mathrm{um}$ & Fthenakis, 2009 \\
\hline Combination & $1.2 \mathrm{um}(\sim 20 \mathrm{yrs})$ & Assumption \\
\hline
\end{tabular}




\begin{tabular}{|c|c|c|}
\hline & $\begin{array}{l}1.0 \text { um (21 30 yrs) } \\
0.8 \text { um (31 yrs ) }\end{array}$ & \\
\hline $\begin{array}{l}\text { Current CIGS module } \\
\text { efficiency ( } \sim 10 \text { years) }\end{array}$ & $11.2 \%$ & Fthenakis, 2009 \\
\hline \multicolumn{3}{|l|}{$\begin{array}{l}\text { Future CIGS module } \\
\text { efficiency ( } 10 \text { years } \sim \text { ) }\end{array}$} \\
\hline Conservative & $14 \%$ & Fthenakis, 2009 \\
\hline Most likely & $15.9 \%$ & Fthenakis, 2009 \\
\hline Optimistic & $16.3 \%$ & Fthenakis, 2009 \\
\hline Combination & $\begin{array}{l}14 \%(\sim 20 \mathrm{yrs}) \\
15.9 \%(21 \sim 30 \mathrm{yrs}) \\
16.3 \%(31 \mathrm{yrs} \sim)\end{array}$ & Assumption \\
\hline Irradiation per year & $1,700 \mathrm{kWh} / \mathrm{m}^{2}$ & $\begin{array}{l}\text { Raugei et al., } 2007 \text { and } \\
\text { Solar GIS } 2015\end{array}$ \\
\hline \multicolumn{3}{|l|}{ Performance ratio } \\
\hline Current ( $\sim 15$ years) & $80 \%$ & Fraunhofer Institute, 2012 \\
\hline Increase (15 years $\sim)$ & $\begin{array}{l}5 \% \text { point increase } \\
\text { every } 15 \text { year up to } \\
90 \%\end{array}$ & Assumption \\
\hline Solar PV lifespan & 28 years & Kumar and Sarkar, 2013 \\
\hline $\begin{array}{l}\text { Current traders' expected } \\
\text { price }\end{array}$ & $\$ 650 / \mathrm{kg}$ & EC, 2015 \\
\hline $\begin{array}{l}\text { Current indium production } \\
\text { cost }\end{array}$ & $\$ 220$ / kg & Gu et al., 2006 \\
\hline
\end{tabular}




\begin{tabular}{|c|c|c|}
\hline $\begin{array}{l}\text { Indium price elasticity of } \\
\text { demand }\end{array}$ & 0.2 & $\begin{array}{l}\text { Stuermer, 2013, } \\
\text { Assumption }\end{array}$ \\
\hline Effect of shortage on price & $\begin{array}{l}\text { 'Yearly indium price } \\
\text { change' }= \\
25.289^{\star} \text { EXP(- } \\
3.056^{\star} \text { (Yearly indium } \\
\text { supply/demand ratio } \\
\text { change)-0.19 }\end{array}$ & $\begin{array}{l}\text { Polinares, } 2012 \text { and } \\
\text { Burgess } 2007\end{array}$ \\
\hline $\begin{array}{l}\text { Operation of indium circuit } \\
\text { (Nominal indium } \\
\text { concentration) }\end{array}$ & 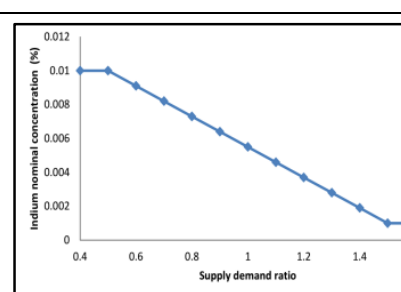 & $\begin{array}{l}\text { Gu et al., } 2006 \text { and Moss } \\
\text { et al., } 2011\end{array}$ \\
\hline
\end{tabular}

\section{A.3. References}

Burgess L. 2007. Indium Demand - Our Indelible Interest in Indium.

http://www.wealthdaily.com/articles/indium-demand-production/3499.

Accessed 20 February 2016

Cenergy Maxpower. 2014. Market share of thin film technologies.

www.cenergymaxpower.com/introduction-solar-pv-modules/. Accessed 10 January. 2015.

EC (European Commission). 2015, Material information system. www.setis.ec.europa.eu/mis/material/indium. Accessed 20 January 2015. 
Goonan, T.G. 2012. Materials flow of indium in the United States in 2008 and 2009 (1377). Reston, VA, USA: U.S. Geological Survey.

Gu, C. , S. Huang, H. Cao, H. Tan, X. Liang, Z. Jiang. 2006. Nandan Country Jilang Indium Manufacturing Co.,Ltd Integrated Indium and Zinc Recovery Project Environmental Impact Statement. Guangxi. China: Scientific Research Academy of Guangxi Environmental Protection.

Fraunhofer Institute. 2012. Photovoltaics report. www.ise.fraunhofer.de/de/downloads/pdf-files/aktuelles/photovoltaicsreport.pdf. Accessed 14 January 2015.

Fthenakis, V. 2009. Sustainability of photovoltaics: The case for thin-film solar cells. Renewable and Sustainable Energy Reviews 13 (9): 2746-2750. DOI:10.1016/j.rser.2009.05.001.

International Monetary Fund (IMF). 2015. World economic outlook - Slower growth in emerging markets, a gradual pickup in advanced economies. Washington, DC: The World Bank.

IZA (International zinc association). 2011a. Zinc recycling: closing the loop. www.zinc.org. Accessed 14 February 2015.

IZA (International zinc association). 2011b. Zinc recycling: material supply. www.zinc.org. Accessed 14 February 2015. 
Kaiser, J.A. 2015. Kaiser research online.

http://www.kaiserbottomfish.com/s/Expresses.asp?ReportID=703881. Accessed 17 February 2016.

Kumar, S and B. Sarkar. 2013. Design for reliability with weibull analysis for photovoltaic modules. International journal of current engineering and technology 3 (1): 129-134.

Moss, R. L., E. Tzimas, H. Kara, P. Willis, and J. Kooroshy. 2011. Critical metals in strategic energy technologies. Assessing rare metals as supply-chain bottlenecks in low-carbon energy technologies. Petten, Netherlands: Institute for Energy and Transport (IET).

NRCan (Natural Resource Canada). 2009. Canadian mineral yearbook: Zinc 2009. Ottawa, Ontario, Canada: Natural Resource Canada.

Niels J., M. Stucki, R. Frischknecht, and ESU-services Ltd., Uster, 2009, Ecoinvent report No. 6 XII Photovoltaic, Swiss Centre for Life Cycle Inventories.

Polinares. 2012. Fact Sheet: Indium. www.polinares.eu/docs/d21/polinares_wp2_annex2_factsheet5_v1_10.pdf. Accessed 31 January 2015. 
Pruyt, E. and TU Delft: Technology, policy and management: Multi actor systems. 2010. Scarcity of minerals and metals: A generic exploratory system dynamics model. System Dynamics Society.

Raugei, M., S. Bargigli, S. Ulgiati, 2007. Life cycle assessment and energy pay-back time of advanced photovoltaic modules: CdTe and CIS compared to poly-Si. Energy, 32: 1310-1318. DOI:10.1016/j.energy.2006.10.003.

Semenza P. 2010. A new chapter for the display market. http://informationdisplay.org/IDArchive/2010/MayJune/DisplayMarketplaceAN ewChapterfortheDisplay.aspx. Accessed 13 January 2015.

Solar GIS. 2015. Map of global horizontal irradiation. www.solargis.info/doc/freesolar-radiation-maps-GHI. Accessed 15 January. 2015.

Stamp, A., P. A. Wäger, and S. Hellweg. 2014. Linking energy scenarios with metal demand modeling-The case of indium in CIGS solar cells. Resources, Conservation and Recycling 93: 156-67.

DOI:10.1016/j.resconrec.2014.10.012.

Stuermer, M. 2013. Industrialization and the Demand for Mineral Commodities. SSRN Electronic Journal. http://doi.org/10.2139/ssrn.2364309 
Tani D. 2015. The world economy - 50 years of near continuous growth. http://www.worldeconomics.com/papers/Global\%20Growth\%20Monitor_7c66f fca-ff86-4e4c-979d-7c5d7a22ef21.paper. Accessed 17 February 2016.

USGS (U. S. Geological Survey). 2009a. Minerals commodity summaries: Indium. 2009. Reston, VA, USA: U.S. Geological Survey.

USGS (U. S. Geological Survey). 2009b. Minerals commodity summaries: Zinc. 2009. Reston, VA, USA: U.S. Geological Survey.

USGS (U. S. Geological Survey). 2011. USGS Mineral Resources Program. 2011. Reston, VA, USA: U.S. Geological Survey.

US SEC (U.S. Securities and Exchange Commission). 2012, Annual report of SMG indium resources $L T D$. www.sec.gov/Archives/edgar/data/1426506/000114420413019117/v336853_ 10k.htm. Accessed 20 January 2015.

World Bank. 2015. Global economic prospect - Having fiscal space and using it. Washington, DC: The World Bank.

Yole development. 2012. Status of LED Industry Report. www.yole.fr/iso_upload/News/2012/PR_Status\%20of\%20the\%20LED\%20Ind ustry_YOLE\%20DEVELOPPEMENT_August2012.pdf. Accessed 4 February 2015. 
Zuser, A. and H. Rechberger. 2011. Considerations of resource availability in technology development strategies: The case study of photovoltaics. Resources, Conservation and Recycling 56 (1): 56-65. DOI:10.1016/j.resconrec.2011.09.004. 